\title{
A comprehensive observation-based multiphase chemical model analysis of sulfur dioxide oxidations in both summer and winter
}

\author{
Huan Song, Keding Lu, Can Ye, Huabin Dong, Shule Li, Shiyi Chen, Zhijun Wu, Mei Zheng, Limin Zeng, Min Hu, \\ and Yuanhang Zhang
}

State Key Joint Laboratory or Environmental Simulation and Pollution Control, College of Environmental Sciences and Engineering, Peking University, Beijing, China

Correspondence: Keding Lu (k.lu@pku.edu.cn)

Received: 5 May 2021 - Discussion started: 31 May 2021

Revised: 4 August 2021 - Accepted: 16 August 2021 - Published: 14 September 2021

\begin{abstract}
Sulfate is one of the main components of haze fine particles, and its formation mechanism remains controversial. A lack of detailed and comprehensive field data hinders the accurate evaluation of relative roles of prevailing sulfate formation pathways. Here, we analyzed the sulfate production rates using a state-of-the-art multiphase model constrained to the observed concentrations of transition metal, nitrogen dioxide, ozone, hydrogen peroxide and other important parameters in winter and summer in the North China Plain. Our results showed that aqueous transition metal ion (TMI)-catalyzed oxidation was the most important pathway followed by the surface oxidation of $\mathrm{Mn}$ in both winter and summer while the hydroxyl and Criegee radical oxidations contribute significantly in summer. In addition, we also modeled the published cases for the fog and cloud conditions. It is found that nitrogen dioxide oxidation is the dominant pathway for the fog in a higher $\mathrm{pH}$ range while hydroperoxide and ozone oxidations dominated for the cloud.
\end{abstract}

\section{Introduction}

Secondary sulfate aerosols are an important component of fine particles in severe haze periods (Zheng et al., 2015; R.J. Huang et al., 2014; Guo et al., 2014), which adversely affect environmental quality and human health (Lippmann and Thurston, 1996; Fang et al., 2017; Shang et al., 2020). Traditional atmospheric models evaluate secondary sulfate formation via the gas-phase oxidation of sulfur dioxide $\left(\mathrm{SO}_{2}\right)$ and a series of multiphase oxidation processes of dissolved $\mathrm{SO}_{2}$ in cloud water. During haze events, multiphase oxida- tion of dissolved $\mathrm{SO}_{2}$ is more important than $\mathrm{SO}_{2}$ directly oxidized by gas-phase radicals (Atkinson et al., 2004; Barth et al., 2002) because of the significantly reduced ultraviolet (UV) radiation intensity due to the aerosol dimming effect. Gas-phase reactions, especially those favoring multiphase chemistry, cannot capture the high concentrations of sulfate aerosols during haze events. Moreover, rapid sulfate production is observed during cloud-free conditions, indicating that aerosol multiphase oxidation may be important during haze periods (Moch et al., 2018). These effects cause a major gap between the measured sulfate concentrations under weak UV radiation and the concentrations calculated using traditional atmospheric models.

Assessing the mechanism of multiphase secondary sulfate formation during haze periods helps evaluate the effect of multiphase oxidation. While the gas-phase oxidation rate of $\mathrm{SO}_{2}$ and $\mathrm{OH}$ is well constrained, there are many uncertainties in the quantification of the relative contribution of each multiphase $\mathrm{SO}_{2}$ oxidation pathway during haze periods. Multiphase oxidation pathways of dissolved $\mathrm{SO}_{2}$ (Seinfeld and Pandis, 2016; P. Liu et al., 2020; Zhu et al., 2020a; Seigneur and Saxena, 1988; $\mathrm{Li}$ et al., 2020b) include oxidation by (1) hydrogen peroxide $\left(\mathrm{H}_{2} \mathrm{O}_{2}\right)$; (2) ozone $\left(\mathrm{O}_{3}\right)$; (3) the transition metal ion (TMI, i.e., Fe (III) and Mn (II))-catalyzed oxidation pathway (aqTMI); and (4) the Mn-catalyzed oxidation of $\mathrm{SO}_{2}$ on aerosol surface pathway (Mn-surface) (Wang et al., 2021). Some studies (Cheng et al., 2016; Wang et al., 2016; Xue et al., 2016; Li et al., 2018) have also suggested that nitrogen oxides may play a crucial role in the explosive growth of sulfate formation during severe haze days in Beijing because of the high $\mathrm{pH}$ near a neutral system, by facil- 
itating the catalysis of mineral dust (Liu et al., 2012; Zhao et al., 2018) or the photolysis of nitrous acid (Zheng et al., 2020). However, the average $\mathrm{pH}$ during Beijing haze periods is approximately 4.2 (Liu et al., 2017), and a high level of $\mathrm{NH}_{3}$ does not increase the aerosol $\mathrm{pH}$ sufficiently to yield $\mathrm{NO}_{2}$-dominated sulfate formation (Guo et al., 2017). Other studies (Ye et al., 2018; T. Liu et al., 2020) have emphasized the importance of $\mathrm{H}_{2} \mathrm{O}_{2}$ oxidation to sulfate formation due to the underestimation of $\mathrm{H}_{2} \mathrm{O}_{2}$ concentrations during haze episodes in previous studies or the influence of the high ionic strength $\left(I_{\mathrm{S}}\right)$ of aerosol solutions on the $\mathrm{H}_{2} \mathrm{O}_{2}$ oxidation rate, which implies that oxidant concentrations for $\mathrm{SO}_{2}$ oxidation constrained to the observed values from field measurements are required. A previous study (Wang et al., 2020) has shown that photosensitization is a new pathway for atmospheric sulfate formation and requires further verification. According to several previous studies of the GEOS-Chem model and including the measurements of oxygen isotopes $\left(\Delta^{17} \mathrm{O}\left(\mathrm{SO}_{4}^{2-}\right)\right)$ (He et al., 2018; Shao et al., 2019; Li et al., 2020a; Yue et al., 2020), it has been shown that the aqTMI was important during some haze periods. Overall, the formation mechanisms of the missing sulfate sources remain unclear and controversial.

Sulfate formation is a complex multiphase physicochemical reaction process in which parameters have multiple interrelationships. Previous studies have mostly selected typical conditions with fixed parameters for numerical calculations, ignoring the fact that sulfate formation is a complex dynamic process. A comprehensive and explicit evaluation of the sulfate generation process requires real-time feedback and explicit constraints of observational data. Therefore, it is crucial to apply constrained parameters from field campaigns in the calculations. Moreover, as proposed in previous studies (Liu et al., 2020b; Cheng et al., 2016), due to the lower water content in aerosol particles than in cloud water, the non-ideality effects of aerosol solutions should be carefully considered.

In this study, we modeled the concentrations of the main reagents of sulfate formation reactions using a state-ofthe-art Peking University Multiple-phAse Reaction Kinetic (PKU-MARK) model based on the data measured in two field campaigns conducted in the winter and summer in the North China Plain (NCP) where several particle pollution episodes happened. The non-ideality of aerosol solutions was considered in the calculation of both gas solubility and aqueous-phase reaction rates. Chemical regimes in the aerosol particle bulk phase were analyzed to understand the role of gas-phase radical precursors, particle TMIs, aerosol surface concentrations and the aerosol liquid water content (ALWC) in the aqueous reactant levels and the sulfate formation rate. All particle concentrations reported are of fine particulate matter with aerodynamic diameters of $2.5 \mu \mathrm{m}$ or less $\left(\mathrm{PM}_{2.5}\right)$.

The overall goal of this work is to evaluate the contribution of different secondary sulfate formation pathways under actual field measurement conditions in the NCP. Effects of non- ideality of the condensed particle phase and the solubility of gas-phase reactants on the reactions enable comparisons with parameters previously obtained in model calculations. In addition, episodes at different pollution levels in the winter and summer campaigns were selected to evaluate the contribution of prevailing sulfate formation pathways proposed in previous studies. As a study evaluating the contribution of different sulfate formation pathways during field campaign observations, this work provides an improved understanding of atmospheric sulfate formation at different pollution levels in the NCP.

\section{Methods}

\subsection{Sampling location and experimental methods}

The data from the 2014 Wangdu (WD-14) and 2017 Peking University (PKU-17) field campaigns, both conducted in summer, were used in our analysis. The WD field campaign was carried out from June to July 2014 at a rural site in Hebei $\left(38.70^{\circ} \mathrm{N}, 115.15^{\circ} \mathrm{E}\right)$ characterized by severe photochemical smog pollution (Tan et al., 2017; Song et al., 2020). The 2017 PKU campaign was performed from November to December 2017 at the campus of Peking University $\left(39.99^{\circ} \mathrm{N}\right.$, $116.31^{\circ} \mathrm{E}$ ), which is in the city center of Beijing and is characterized by strong local anthropogenic emissions from two major roads (Ma et al., 2019).

Observations from both field campaigns include gas-phase measurements of $\mathrm{SO}_{2}$ and $\mathrm{O}_{3}$ from commercial Thermo Scientific monitors and $\mathrm{NO}_{2}$ detected after conversion through a custom-built photolytic converter with a UV LED at $395 \mathrm{~nm}$ and aerosol number concentration and distribution from a set of commercial particle instruments containing a scanning mobility nanoparticle sizer (SMPS) and aerodynamic particle sizer (APS) to cover the size range of $3 \mathrm{~nm}$ to $10 \mu \mathrm{m}$. The mass concentration of $\mathrm{PM}_{2.5}$ was measured by a commercial ambient particulate monitor (TEOM). The in situ gas and aerosol compositions monitor (IGAC) (Young et al., 2016), which can collect gases and particles simultaneously, was used to measure water-soluble ions online with a $1 \mathrm{~h}$ time resolution. Both gas and aerosol samples were injected into $10 \mathrm{~mL}$ glass syringes, which were connected to an ion chromatograph (IC) for analysis (30 min time resolution for each sample). The concentrations of eight water-soluble inorganic ions $\left(\mathrm{NH}_{4}^{+}, \mathrm{Na}^{+}, \mathrm{K}^{+}, \mathrm{Ca}^{2+}, \mathrm{Mg}^{2+}, \mathrm{SO}_{4}^{2-}, \mathrm{NO}_{3}^{-}\right.$and $\left.\mathrm{Cl}^{-}\right)$in fine particles were measured. Transition metal ( $\mathrm{Fe}$ and $\mathrm{Cu}$ ) concentrations in $\mathrm{PM}_{2.5}$ were measured using an Xact 625 ambient metal monitor. With Xact, ambient air was introduced through a $\mathrm{PM}_{2.5}$ cyclone inlet at a constant flow rate of $16.7 \mathrm{~L} / \mathrm{min}$ and collected on the reel-to-reel polytetrafluoroethylene filter. Then trace elements in ambient fine particles on the filter were automatically detected using the United States Environmental Protection Agency (US EPA) standard method via $\mathrm{x}$-ray fluorescence (XRF) analysis (Gao 
et al., 2016; Zhang et al., 2019). Ambient temperature and pressure data were measured using commercial meteorological sensors; selected volatile organic compounds (VOCs) were measured via off-line gas chromatography-mass spectrometry (GC-MS) in tower measurements using sampling canisters and via online GC-MS in the surface campaign. The $\mathrm{OH}$ and $\mathrm{HO}_{2}$ concentrations were measured via laserinduced fluorescence (LIF) with a time resolution of $30 \mathrm{~s}$ as described in a previous study (Ma et al., 2019). The concentrations of gas-phase peroxides were measured using highperformance liquid chromatography (HPLC; Agilent 1200, USA) with a time resolution of $21 \mathrm{~min}$.

\subsection{Brief overview of the PKU-MARK model}

The Multiple-phAse Reaction Kinetic (PKU-MARK) model was first developed to calculate the heterogeneous reaction rate of reactive gas molecules (Song et al., 2020). The units of aqueous reagents are converted to molecules $/ \mathrm{cm}^{3}$ in the model by a factor $k_{\mathrm{mt}}$, which combines both gas-phase molecular diffusion and liquid-phase interface mass transport processes (Schwartz, 1984, 1986) and is used in the calculation for gas-liquid multiphase reactions in many modeling studies (Lelieveld and Crutzen, 1991; Chameides and Stelson, 1992a; Sander, 1999; Hanson et al., 1994; Song et al., 2020). In this study, the PKU-MARK model was further developed with the correction of ionic strength for all ions and reactants and applied to a size-segregated system to investigate the influence of aerosol particle size distribution and ALWC distribution. Eleven bins of aerosol particle diameter and corresponding ALWC values were applied in the model. With the input of $1 \mathrm{~h}$ averaged parameters observed in the field campaign, the PKU-MARK model produced the steadystate concentrations of aqueous reactants including reactive oxygen species $\left(\mathrm{H}_{2} \mathrm{O}_{2}, \mathrm{O}_{3}, \mathrm{OH}, \mathrm{HO}_{2}, \mathrm{O}_{2}^{-}\right), \mathrm{Fe}$ (III), $\mathrm{Mn}$ (II), $\mathrm{SO}_{2(\mathrm{aq})}$ and $\mathrm{NO}_{2(\mathrm{aq})}$. Considering the mutual influence of various factors in the reaction system can effectively prevent bias caused by arbitrarily fixing a certain value as was often carried out in previous studies.

\subsection{Calculation of aerosol $\mathrm{pH}$, aerosol liquid water and ionic strength}

ALWC and aerosol $\mathrm{pH}$ were calculated using the ISORROPIA II model and measured concentrations of inorganic ions in particles. ISORROPIA II is a thermodynamic equilibrium model that predicts the physical state and composition of atmospheric inorganic aerosols. Its ability to predict $\mathrm{pH}$ has been demonstrated in detail in previous studies (Guo et al., 2015; Xu et al., 2015). Ionic strength was calculated via Eq. (2) (Ross and Noone, 1991):

$I_{\mathrm{S}}=\frac{1}{2} \cdot \sum m_{\mathrm{i}} \cdot z_{\mathrm{i}}^{2}$,

where $m_{\mathrm{i}}$ is the molality of an ion $(\mathrm{mol} / \mathrm{L})$ and $z_{\mathrm{i}}$ is the corresponding charge. In the PKU-MARK model, reaction rates were replaced by the activity coefficient. The ionic strength was estimated using the ISORROPIA II model assuming that the condensed phase is in a meta-stable state and there is a complete external mixing state.

In order to consider the influence of the particle diameter on aqueous $\mathrm{SO}_{2}$ concentrations, which is key to calculating sulfate formation, we used an 11-bin actual particle diameter distribution rather than one even distribution used in previous studies (Cheng et al., 2016). The distribution of particle number concentration and water content is illustrated in Fig. S2. We also considered the distribution of ALWC in different particle diameter bins based on the $\kappa$-Köhler theory (Petters and Kreidenweis, 2007) using observed kappa values from a high-humidity tandem differential mobility analyzer (HH-TDMA) and a twin differential mobility particle sizer (TDMPS)-APS (Bian et al., 2014). Calculated ALWC values were strongly correlated with the ISORROPIA II results (Fig. S3).

To combine both gas-phase molecular diffusion and liquid-phase interface mass transport processes, the approach adopted in this study uses one variable called $k_{\mathrm{mt}}$ (Schwartz, 1984, 1986), which is used in multiphase reactions in many modeling studies (Lelieveld and Crutzen, 1991; Chameides and Stelson, 1992b; Sander, 1999; Hanson et al., 1994). The definition of $k_{\mathrm{mt}}$ is given in Eq. (3):

$k_{\mathrm{mt}}=\left(\frac{R_{d}^{2}}{3 D_{g}}+\frac{4 R_{d}}{3 v_{\mathrm{HO}_{2}} \alpha}\right)^{-1}$.

The rate of gas-phase reactions $(X)$ diffusing and dissolving to the condensed phase can be calculated in the framework of aqueous-phase reactions as $k_{\mathrm{mt} \_} X \times \mathrm{ALWC}$, where $X$ is the reactant molecule (please see Table S8 for more details). Moreover, the conversion rate of aqueous-phase reactions to gas-phase reactions can be calculated as $\frac{k_{\mathrm{mt} X} X}{H^{\mathrm{cc}} \times R T}$. The unit of $k_{\mathrm{mt}}$ is inverse seconds $\left(\mathrm{s}^{-1}\right)$, as $k_{\mathrm{mt}}$ contains the conversion from inverse cubic meters $\left(\mathrm{m}^{-3}\right)$ of air of the gasphase molecule concentrations to inverse cubic meters $\left(\mathrm{m}^{-3}\right)$ of the aqueous-phase molecule concentrations. Particle diameter can influence the mass transport rate of $\mathrm{SO}_{2}$ and its aqueous concentration. Based on the model results of Xue et al. (2016), diameter had an impact on sulfate formation rates: for larger particles (radius $>1 \mu \mathrm{m}$ ), $k_{\mathrm{mt}}$ is determined by gas-phase diffusion; for smaller particles (radius $<1 \mu \mathrm{m}$ ), $k_{\mathrm{mt}}$ is determined by the accommodation process. The PKUMARK model can simultaneously simulate two-phase (gas and liquid) reaction systems in the same framework.

\subsection{Model evaluation}

Concentrations of sulfate were calculated by integrating an extension of the Eulerian box model described in a previous study (Seinfeld and Pandis, 2016). Sulfate concentrations are related to dry deposition, transport, dilution as the boundary layer height (BLH) expands, emissions and net production. 
Due to the higher and more dramatically diurnally changing BLH in summer (Lou et al., 2019) and the lack of relevant data in the WD-14 field campaign, we could not achieve the modeled results of sulfate concentrations in summer haze periods. Direct emissions and transport of sulfate were not considered in the calculation because secondary sulfate is the predominant source in winter haze periods. Dilution was not considered either because the atmosphere is relatively homogeneous during winter haze episodes. Since haze events are normally accompanied by a low boundary layer height $\left(H_{t}\right), H_{t}$ was set at $300 \mathrm{~m}$ in the nighttime and $450 \mathrm{~m}$ at noon (Xue et al., 2016). At other times, $H_{t}$ was estimated using a polynomial $(n=2)$ regression as recommended in a previous study (Xue et al., 2016). The diurnal trends of sulfate concentrations of the winter haze period and in summer using the deposition velocity of 1.5 and $2 \mathrm{~cm} / \mathrm{s}$, respectively, are shown in Fig. 1c and d. Model results had the same trend as the observed values and could explain the missing source of sulfate aerosols to some extent in winter with high uncertainties in summer.

\section{Results}

\subsection{Overview of the field observations}

Table 1 shows the key meteorological parameters, trace gases concentrations, calculated ALWC, ionic strength, $\mathrm{pH}$ and sulfate formation rates under different pollution conditions in the PKU-17 and WD-14 comprehensive field campaigns. The sampling location and experimental methods used in these two campaigns are summarized in the Methods section. The pollution degree is classified according to the mass concentration of $\mathrm{PM}_{2.5}$. The clean condition means $\mathrm{PM}_{2.5}$ smaller than $35 \mu \mathrm{g} / \mathrm{m}^{3}$; the slightly polluted condition is $35-75 \mu \mathrm{g} / \mathrm{m}^{3}$; the polluted condition is $75-150 \mu \mathrm{g} / \mathrm{m}^{3}$; and highly polluted is larger than $150 \mu \mathrm{g} / \mathrm{m}^{3}$. Sulfate formation rates were modeled by the Multiple-phAse Reaction Kinetic (PKU-MARK) model (mentioned in Methods) with constrained parameters. The effects of aerosol non-ideality were considered in the size-segregated model. Data points with relatively humidity (RH) smaller than $20 \%$ and ALWC smaller than $1 \mu \mathrm{g} / \mathrm{m}^{3}$ were abandoned to improve the accuracy of the results.

Transition metal concentrations including those of $\mathrm{Fe}$ and Mn increased with PM mass (as shown in Fig. 1). Photochemical oxidants including $\mathrm{H}_{2} \mathrm{O}_{2}$ and $\mathrm{O}_{3}$ exhibited a decreasing trend with the increase in PM mass because of the significantly reduced solar ultraviolet (UV) radiation intensity due to the aerosol dimming effect. Some studies have reported high $\mathrm{H}_{2} \mathrm{O}_{2}$ concentrations during haze episodes (Ye et al., 2018), whereas in the PKU-17 field campaign, the average concentration of $\mathrm{H}_{2} \mathrm{O}_{2}$ was only $20.9 \pm 22.8 \mathrm{pptV}$ in highly polluted conditions. Higher sulfate concentration was observed in the high range of RH and ALWC, indicating their enhancement effects on the sulfate formation. We also picked four haze periods in the PKU-17 observation; the time series of these key parameters are provided in the Supplement Fig. S4.

Aerosol $\mathrm{pH}$ values were calculated using the ISORROPIA II model. The calculated particle $\mathrm{pH}$ values as shown in Table 1 are in good agreement with the values reported in other studies (Guo et al., 2017; Weber et al., 2016). The lower $\mathrm{pH}$ in the range of 4.0-5.5 is beneficial to sulfate formation via the aqTMI. Aerosol liquid water is another key component: higher loading of aerosol liquid water is more conducive to the occurrence of multiphase reactions. The ALWC in the PKU-17 and WD-14 campaigns was calculated via the ISORROPIA II model with input concentrations of aerosol inorganic components (see Sect. 2.3). Aerosol liquid water did not freeze at winter temperatures below $273 \mathrm{~K}$ in the PKU field campaign because of the salt-induced freezing point depression (Koop et al., 2000). Wind speeds during these haze events were persistently low $(0.3-1.5 \mathrm{~m} / \mathrm{s})$, indicating the minor contribution of regional transport to sulfate production.

The aqueous TMI concentration level is crucial in the evaluation of secondary sulfate formation in real atmospheric conditions. Atmospheric anthropogenic sources of transition metals such as iron $(\mathrm{Fe})$ are crust related, and the peak concentration of $\mathrm{Fe}$ in Beijing is correlated to vehicle driving in traffic rush hours. Copper $(\mathrm{Cu})$ and manganese $(\mathrm{Mn})$ are mainly from non-exhaust emissions of vehicles, fossil fuel combustion or metallurgy (Alexander et al., 2009; Duan et al., 2012; Zhao et al., 2021). Concentrations of transition metals are highly variable, ranging from $<0.1$ to $>1000 \mathrm{ng} / \mathrm{m}^{3}$ globally (Alexander et al., 2009). Fe solubility in atmospheric aerosols has been reported to range from $0.1 \%$ to $80 \%$ (Ito et al., 2019; Hsu et al., 2010; Heal et al., 2005; Shi et al., 2012; Mahowald et al., 2005), and elevated levels of Fe solubility have been observed in aerosols dominated by combustion sources. The average fractional Fe solubility in areas away from dust source regions is typically between 5\% and 25\% (Baker and Jickells, 2006; Baker et al., 2006; Hsu et al., 2010). A recent study reported the average Fe solubility as $2.7 \%-5.0 \%$ in Chinese cities, and more than $65 \%$ of nano-sized Fe-containing particles were internally mixed with sulfates and nitrates (Zhu et al., 2020b). The solubility of Mn tends to be higher than that of Fe (Baker et al., 2006), which is $22 \%-57 \%$ in urban aerosol particles (X. Huang et al., 2014). In this study, we chose the solubility of total $\mathrm{Fe}$ as $5 \%$ and total Mn solubility as $50 \%$ assuming that aerosol particles are internally mixed. In Beijing, high concentrations of $\mathrm{Fe}, \mathrm{Cu}$ and $\mathrm{Mn}$ were observed (Table S9). Concentrations of transition metals are strongly correlated during these haze periods; thus, we propose a fixed ratio of $\mathrm{Fe} / \mathrm{Mn}$ to account for the lack of Mn data in the PKU-17 and WD-14 field campaigns (Sect. S2).

Aerosol trace metal speciation and water solubility are affected by factors such as photochemistry, aerosol $\mathrm{pH}$ and 
Table 1. Averaged results of observed meteorological parameters: trace gas concentrations; transition metal concentrations such as those of $\mathrm{Fe}, \mathrm{Cu}$ and $\mathrm{Mn}$; calculated ALWC; ionic strength; $\mathrm{pH}$; and sulfate formation rates in different pollution conditions in two field campaigns $( \pm 1 \sigma)$.

\begin{tabular}{|c|c|c|c|c|}
\hline Parameters & Clean & Slightly polluted & Polluted & Highly polluted \\
\hline \multicolumn{5}{|l|}{ Winter } \\
\hline $\mathrm{RH}(\%)$ & $25.0 \pm 8.3$ & $37.1 \pm 11.5$ & $44.8 \pm 11.9$ & $63.6 \pm 19.5$ \\
\hline Temperature $(\mathrm{K})$ & $273.0 \pm 4.6$ & $274.1 \pm 3.3$ & $273.6 \pm 2.6$ & $273.8 \pm 2.3$ \\
\hline $\mathrm{SO}_{2}(\mathrm{ppbV})$ & $2.4 \pm 1.4$ & $5.8 \pm 2.0$ & $6.5 \pm 2.6$ & $5.5 \pm 3.0$ \\
\hline $\mathrm{NO}_{2}(\mathrm{ppbV})$ & $21.1 \pm 10.4$ & $37.6 \pm 6.3$ & $44.1 \pm 6.1$ & $57.6 \pm 8.7$ \\
\hline $\mathrm{OH}\left(\mathrm{molec} . / \mathrm{cm}^{3}\right)$ & $(4.67 \pm 3.73) \times 10^{5}$ & $(5.02 \pm 5.22) \times 10^{5}$ & $(4.42 \pm 2.78) \times 10^{5}$ & $(4.36 \pm 3.06) \times 10^{5}$ \\
\hline $\mathrm{H}_{2} \mathrm{O}_{2}(\mathrm{pptV})$ & $29.8 \pm 20.8$ & $23.5 \pm 27.2$ & $19.5 \pm 39.6$ & $20.9 \pm 22.8$ \\
\hline $\mathrm{O}_{3}(\mathrm{ppbV})$ & $14.8 \pm 11.9$ & $3.2 \pm 5.7$ & $2.1 \pm 2.7$ & $1.1 \pm 1.2$ \\
\hline $\mathrm{SO}_{4}^{2-}\left(\mu \mathrm{g} / \mathrm{m}^{3}\right)$ & $3.5 \pm 1.5$ & $6.4 \pm 3.5$ & $8.3 \pm 4.2$ & $16.6 \pm 6.6$ \\
\hline $\mathrm{Fe}\left(\mathrm{ng} / \mathrm{m}^{3}\right)$ & $348.4 \pm 263.0$ & $564.2 \pm 188.2$ & $725.5 \pm 258.6$ & $1300.6 \pm 289.5$ \\
\hline $\mathrm{Cu}\left(\mathrm{ng} / \mathrm{m}^{3}\right)$ & $7.0 \pm 5.0$ & $13.8 \pm 4.2$ & $18.7 \pm 6.0$ & $29.3 \pm 6.6$ \\
\hline $\operatorname{Mn}\left(\mathrm{ng} / \mathrm{m}^{3}\right)$ & $12.4 \pm 9.4$ & $20.1 \pm 6.7$ & $25.9 \pm 9.2$ & $46.5 \pm 10.3$ \\
\hline $\operatorname{ALWC}\left(\mu \mathrm{g} / \mathrm{m}^{3}\right)$ & $3.1 \pm 2.6$ & $3.8 \pm 4.4$ & $11.9 \pm 15.6$ & $82.4 \pm 67.3$ \\
\hline Surface area $\left(\mu \mathrm{m}^{2} / \mathrm{cm}^{3}\right)$ & $263.2 \pm 171.5$ & $714.3 \pm 242.2$ & $1253.3 \pm 448.9$ & $2628.6 \pm 1164.4$ \\
\hline $\mathrm{PM}_{2.5}\left(\mu \mathrm{g} / \mathrm{m}^{3}\right)$ & $18.3 \pm 10.1$ & $52.0 \pm 10.0$ & $101.7 \pm 18.2$ & $190.0 \pm 30.0$ \\
\hline $\mathrm{pH}$ & $4.43 \pm 1.12$ & $4.52 \pm 0.76$ & $4.93 \pm 0.57$ & $4.77 \pm 0.39$ \\
\hline Ionic strength $(\mathrm{M})$ & $170.34 \pm 88.32$ & $89.32 \pm 55.19$ & $61.59 \pm 38.7$ & $36.27 \pm 36.93$ \\
\hline $\mathrm{d}[\mathrm{S}(\mathrm{VI})] / \mathrm{d} t\left(\mu \mathrm{g} / \mathrm{m}^{3} / \mathrm{h}\right)$ & $1.3 \pm 1.88$ & $2.25 \pm 2.15$ & $2.35 \pm 2.19$ & $3.98 \pm 2.75$ \\
\hline \multicolumn{5}{|l|}{ Summer } \\
\hline $\mathrm{RH}(\%)$ & $69.5 \pm 17.9$ & $64.4 \pm 18.4$ & $66.4 \pm 13.0$ & $65.6 \pm 7.7$ \\
\hline Temperature $(\mathrm{K})$ & $296.5 \pm 3.6$ & $298.5 \pm 4.4$ & $299.1 \pm 2.9$ & $298.9 \pm 3.1$ \\
\hline $\mathrm{SO}_{2}(\mathrm{ppbV})$ & $2.4 \pm 2.0$ & $4.6 \pm 4.4$ & $5.6 \pm 5.0$ & $7.9 \pm 4.0$ \\
\hline $\mathrm{NO}_{2}(\mathrm{ppbV})$ & $8.7 \pm 4.9$ & $9.6 \pm 5.6$ & $9.0 \pm 5.5$ & $12.3 \pm 6.1$ \\
\hline $\mathrm{OH}\left(\right.$ molec. $\left./ \mathrm{cm}^{3}\right)$ & $(2.38 \pm 2.44) \times 10^{5}$ & $(3.27 \pm 3.21) \times 10^{5}$ & $(2.77 \pm 2.26) \times 10^{5}$ & $(3.50 \pm 3.38) \times 10^{5}$ \\
\hline $\mathrm{H}_{2} \mathrm{O}_{2}(\mathrm{pptV})$ & $466.2 \pm 571.6$ & $355.5 \pm 488.0$ & $596.1 \pm 777.0$ & $173.6 \pm 348.6$ \\
\hline $\mathrm{O}_{3}(\mathrm{ppbV})$ & $46.0 \pm 30.3$ & $50.9 \pm 30.6$ & $53.0 \pm 26.6$ & $48.5 \pm 28.5$ \\
\hline $\mathrm{SO}_{2}^{4-}\left(\mu \mathrm{g} / \mathrm{m}^{3}\right)$ & $7.2 \pm 2.6$ & $11.0 \pm 4.9$ & $17.8 \pm 6.0$ & $24.4 \pm 6.0$ \\
\hline $\mathrm{Fe}\left(\mathrm{ng} / \mathrm{m}^{3}\right)$ & $521.6 \pm 286.6$ & $469.3 \pm 151.7$ & $535.2 \pm 177.0$ & $730.9 \pm 156.6$ \\
\hline $\mathrm{Cu}\left(\mathrm{ng} / \mathrm{m}^{3}\right)$ & $26.6 \pm 18.8$ & $37.7 \pm 31.8$ & $33.8 \pm 26.0$ & $47.1 \pm 36.3$ \\
\hline $\operatorname{Mn}\left(n g / m^{3}\right)$ & $18.6 \pm 10.2$ & $16.8 \pm 5.4$ & $19.1 \pm 6.3$ & $26.1 \pm 5.6$ \\
\hline $\operatorname{ALWC}\left(\mu \mathrm{g} / \mathrm{m}^{3}\right)$ & $31.8 \pm 30.9$ & $35.7 \pm 32.8$ & $48.6 \pm 31.4$ & $58.8 \pm 14.4$ \\
\hline Surface area $\left(\mu \mathrm{m}^{2} / \mathrm{cm}^{3}\right)$ & $767.8 \pm 265.6$ & $925.0 \pm 213.9$ & $1389.0 \pm 312.6$ & $1711.1 \pm 729.6$ \\
\hline $\mathrm{PM}_{2.5}\left(\mu \mathrm{g} / \mathrm{m}^{3}\right)$ & $20.1 \pm 10.2$ & $54.9 \pm 11.7$ & $104.8 \pm 20.5$ & $194.6 \pm 32.9$ \\
\hline $\mathrm{pH}$ & $4.48 \pm 0.48$ & $4.19 \pm 0.66$ & $4.17 \pm 0.48$ & $4.33 \pm 0.44$ \\
\hline Ionic strength $(\mathrm{M})$ & $20.04 \pm 17.53$ & $25.44 \pm 20.83$ & $24.27 \pm 14.06$ & $24.2 \pm 9.19$ \\
\hline $\mathrm{d}[\mathrm{S}(\mathrm{VI})] / \mathrm{d} t\left(\mu \mathrm{g} / \mathrm{m}^{3} / \mathrm{h}\right)$ & $2.13 \pm 2.03$ & $3.81 \pm 4.22$ & $3.79 \pm 5.66$ & $5.6 \pm 4.45$ \\
\hline
\end{tabular}

The concentration of $\mathrm{Mn}$ was estimated based on the ratio of Fe/Mn observed in urban Beijing in the literature (summarized in Table S9). All mentioned aerosol data have particle matter diameters smaller than $2.5 \mu \mathrm{m}$, and $\mathrm{PM}_{2.5}$ refers to the dry mass concentration of fine particulate matters.

aerosol particle size (Baker and Jickells, 2006; Oakes et al., 2010). Soluble iron in aerosol water exists as Fe (II) and Fe (III), with a series of redox recycling between the two species and other ions. Partitioning between Fe (II) and Fe (III) varies diurnally with the highest fraction of Fe (II) found during the day because of the photochemical reactions reducing $\mathrm{Fe}$ (III) to Fe (II). Photolysis reactions of iron hydroxides and organic complexes were documented as the most important source of $\mathrm{Fe}$ (II) in cloud and fog water. Oxalic acid and its deprotonated form, oxalate, have strong coordination ability with $\mathrm{Fe}$ and form Fe-oxalate complexes, which have higher photochemical activity than Fe hydroxide. All these mechanisms are included in the PKU-MARK model. Diurnal trends of sulfate formation were observed during haze periods, indicating the diurnal distribution of different states of iron. Redox cycling of other TMIs such as $\mathrm{Cu}$ and $\mathrm{Mn}$ is also considered in the PKU-MARK model. The averaged percentage of soluble Fe (III) and Mn (II) was $0.79 \%$ and $19.83 \%$ in polluted winter conditions and $2.57 \%$ and $52.15 \%$ in polluted summer conditions. The main reason for the difference 

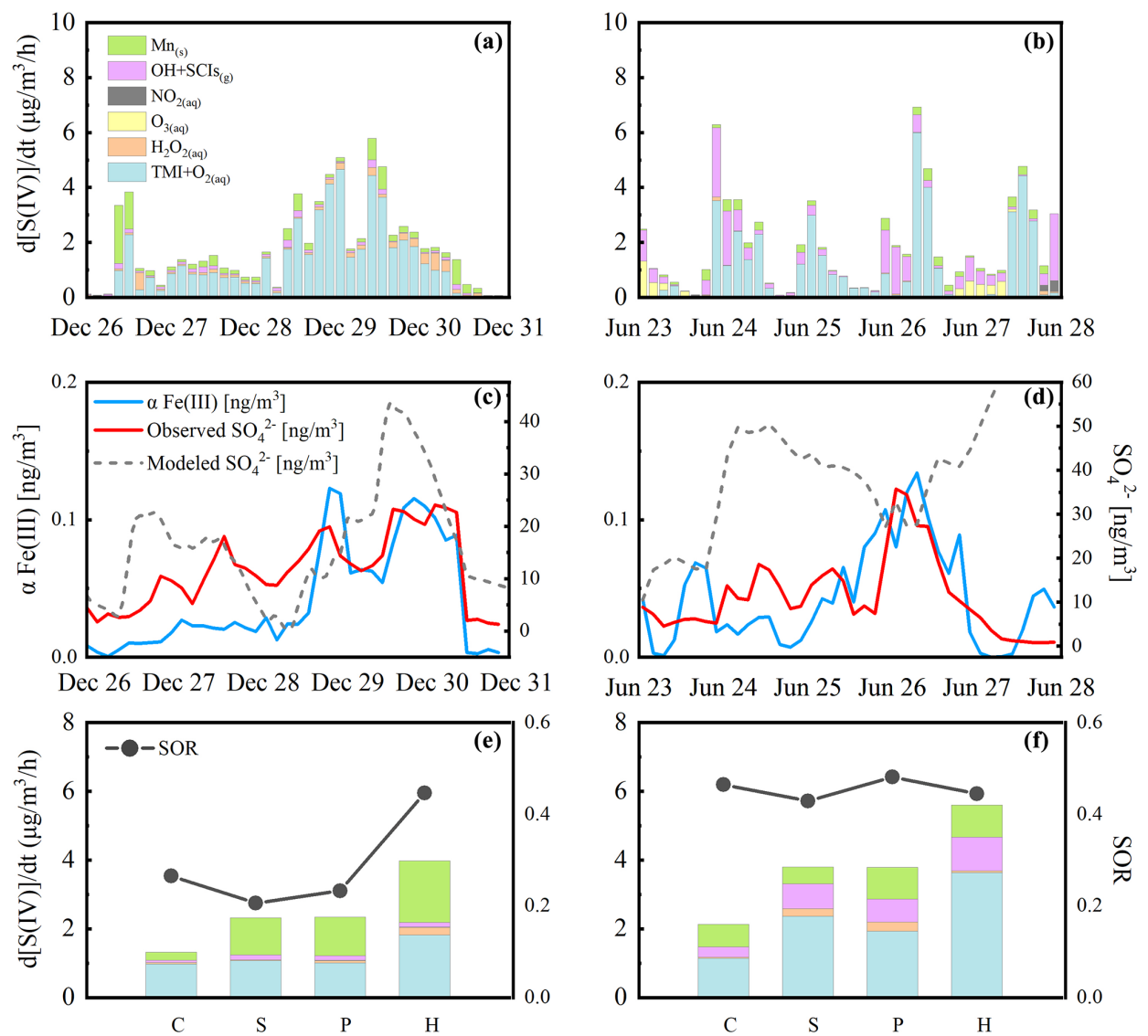

Figure 1. The $3 \mathrm{~h}$ average sulfate formation rates during haze periods in winter and summer (a, b). Corresponding effective Fe (III) concentrations and sulfate concentrations (c, d). Sulfate formation rates (the histogram) and the sulfate oxidation ratio (SOR; dotted lines) at different pollution levels in two field campaigns $(\mathbf{e}, \mathbf{f})$. The contributions to sulfate formation from each multiphase oxidant pathway including Mn-surface oxidant (green), gas-phase $\mathrm{OH}$ radical and stabilized Criegee intermediate (SCI) oxidant (pink), aqueous-phase $\mathrm{NO}_{2}$ (grey), $\mathrm{O}_{3}$ (yellow), $\mathrm{H}_{2} \mathrm{O}_{2}$ (orange), and the aqTMI (blue) are colored in the figure. Obvious particle growth and removal are observed in winter (26 to 31 December 2017), and diurnal variation patterns of sulfate concentration are observed in summer (23 to 28 June 2014 ). Diurnal trends of the modeled winter period's sulfate concentration (dashed grey line) using deposition velocity at $1.5 \mathrm{~cm} / \mathrm{s}$ in winter and $2 \mathrm{~cm} / \mathrm{s}$ in summer are illustrated in panels (c) and (d). The dotted lines in the (e) winter and (f) summer indicate the SOR with pollution levels across the whole of each campaign and the capitalized letters C, S, P and H are abbreviations for "clean", "slightly polluted", "polluted" and "highly polluted", respectively.

between winter and summer metal solubility is that summer aerosols have higher water content and lower ionic strength, which is conducive to the dissolution of Fe and Mn. The solubility range is in good agreement with the values reported in previous observations (Ito et al., 2019; Hsu et al., 2010).

The influence of aerosol ionic strength on aqTMI reaction rates was considered carefully in the study. Higher ALWC is typically accompanied by lower ionic strength, which increases the activity of TMIs. The relationship (T. Liu et al., 2020) between the rate coefficients of the TMI pathway and ionic strength is displayed in Fig. S1. The sulfate formation rate decreased by 424.82 times when ionic strength was $45 \mathrm{M}$ compared to the dilute solution with an ionic strength of $0 \mathrm{M}$. Despite considering the effect of the activity coefficient on the reaction rate of the aqTMI, the contribution of the aqTMI was still dominant during haze periods, indicating that the dominance of the aqTMI can be a widespread phenomenon, as recommended in previous studies (He et al., 2018; Shao et al., 2019; Li et al., 2020a; Yue et al., 2020).

\subsection{Analysis of sulfate formation rate in different pollution conditions}

Figure 1a and $\mathrm{b}$ display the $3 \mathrm{~h}$ averaged sulfate formation rates in the PKU-17 and WD-14 during haze periods. Contributions of the gas-phase radical oxidants were much higher during summertime. To fully explain the relative contributions to sulfate formation from different pathways, the stabilized Criegee intermediate (SCI) oxidant was also considered in the calculations. Based on the previous report (Sarwar et al., 2013), the inclusion of the SCI oxidation pathway further enhances sulfate production. We modified the Regional 
Atmospheric Chemistry Mechanism (RACM2) (Goliff et al., 2013; Goliff and Stockwell, 2008) to represent three explicit SCIs and their subsequent reactions (Welz et al., 2012) with $\mathrm{SO}_{2}, \mathrm{NO}_{2}$, aldehydes, ketones, water monomers and water dimmers and calculated the contribution of this pathway in two field campaigns.

The contribution of the aqTMI increased rapidly with the aggravated pollution. High concentrations of transition metals observed in Beijing facilitated the dissolution of $\mathrm{Fe}, \mathrm{Cu}$ and $\mathrm{Mn}$. The relationship of ionic strength and the aqTMI rate constant is illustrated in Fig. S1 and Table S2 (T. Liu et al., 2020). $\alpha \mathrm{Fe}$ (III) is defined as the product of the $\mathrm{Fe}$ (III) activity coefficient, concentration, molecular weight (56) and aerosol liquid water content. Compared to the total Fe concentration, it is more effective to evaluate the impact of $\alpha \mathrm{Fe}$ (III) on sulfate formation. The relationship between $\alpha \mathrm{Fe}$ (III) and the sulfate oxidation ratio (SOR; $\equiv$ $n\left(\mathrm{SO}_{2}\right) / n\left(\mathrm{SO}_{2}+\mathrm{SO}_{4}^{2-}\right)$, defined as the ratio of the molar concentration of $\mathrm{SO}_{2}$ to the sum of $\mathrm{SO}_{2}$ and $\mathrm{SO}_{4}^{2-}$ molar concentrations) in the PKU-17 winter field campaign is shown in Fig. S5. Because of the inhibition of the effects of high ionic strength on the rate constant of the aqTMI, a high volume of aerosol water during the haze event increased the TMI activity coefficient, benefiting sulfate formation. Obvious correlations between $\alpha \mathrm{Fe}$ (III) and sulfate concentration shown in Fig. 1c and d were observed in the haze periods in both summer $\left(R^{2}=0.63\right)$ and winter $\left(R^{2}=0.71\right)$, and the correlation is consistent with the important contributions from the aqTMI to the sulfate formation. Affected by the higher boundary layer height and higher gas-phase radical concentration in summer, the correlation between the SOR and PM mass in summer is not as significant as that in winter. In summer, as illustrated in Fig. S6, there was still an obvious positive dependence between the SOR and RH and ALWC, whereas a negative correlation was found between the SOR and odd oxygen $\left([\mathrm{Ox}] \equiv\left[\mathrm{O}_{3}\right]+\left[\mathrm{NO}_{2}\right]\right)$. As shown in Fig. 1e and $\mathrm{f}$, the sulfate formation through gaseous reaction was more important in summer than in winter, mainly provided by gas-phase radicals (OH and SCIs). In the WD-14 field campaign, heterogeneous aqTMIs were still dominant in the secondary sulfate formation.

\subsection{Dependence of the secondary sulfate formation rates on aerosol $\mathrm{pH}$ and water content}

Aerosol $\mathrm{pH}$ and ALWC were calculated using the ISORROPIA II model (Sect. 2.3). Because of the high sensitivity of sulfate formation to $\mathrm{pH}$, the lower range of aerosol $\mathrm{pH}$ during these two campaigns made the aqTMI the most important one. The effects of high aerosol ionic strength on the dissolution equilibrium and reaction rates were considered in calculations (T. Liu et al., 2020) (Tables S2-S4). Due to the low $\mathrm{H}_{2} \mathrm{O}_{2}$ concentration $(\sim 0.023 \mathrm{ppbV})$ and low ALWC observed in the PKU-17 field campaign, the average contribution of $\mathrm{H}_{2} \mathrm{O}_{2}$ in haze periods $\left(\mathrm{PM}_{2.5}>75 \mu \mathrm{g} / \mathrm{m}^{3}\right)$ was about $0.11 \pm 0.15 \mu \mathrm{g} / \mathrm{m}^{3} / \mathrm{h}$. Higher gas-phase $\mathrm{H}_{2} \mathrm{O}_{2}$ concentration may further increase the contribution of this pathway to sulfate formation. Based on a recent report (Ye et al., 2018), higher gas-phase $\mathrm{H}_{2} \mathrm{O}_{2}$ concentrations were observed in the NCP during different haze events, including severe haze episodes in suburban areas. At $0.1 \mathrm{ppbV} \mathrm{H}_{2} \mathrm{O}_{2}$ (about 5 times higher than the observed $\mathrm{H}_{2} \mathrm{O}_{2}$ concentration), the calculated sulfate formation rate was $0.52 \pm 0.76 \mu \mathrm{g} / \mathrm{m}^{3} / \mathrm{h}$ in haze periods with great uncertainty and still lower than the contribution of the TMI pathway $\left(1.17 \pm 1.48 \mu \mathrm{g} / \mathrm{m}^{3} / \mathrm{h}\right)$.

Due to the potential interaction between various factors in the atmosphere, fixing certain parameters and changing only the $\mathrm{pH}$ to obtain the sulfate production rate may cause errors. With the development of haze, concentrations of $\mathrm{O}_{3}$ and $\mathrm{OH}$ radicals decrease due to reduced UV radiation caused by the aerosol dimming effect. Despite its minor contribution to sulfate production in winter, the increase in the ozone oxidation rate with $\mathrm{pH}$ was slower under actual conditions. Contributions of gas-phase radicals also showed a weak downward trend in the summer campaign (Fig. 2c). The bias between calculated and observed values indicated a dynamic balance of atmospheric oxidation in the gas phase and aerosol phase. If we arbitrarily use the average values during haze periods and only change the $\mathrm{pH}$ of the aerosols as in previous studies, the obtained sulfate production rate will deviate from the observed values. Actual ambient sulfate formation rates calculated using the measured values in polluted periods in two field campaigns are illustrated in Fig. 2a and c. Average values except for $\mathrm{pH}$ during the haze periods were used to calculate the sulfate formation rates as shown in Fig. $2 b$ and d. The peak of the $\mathrm{H}_{2} \mathrm{O}_{2}$ line in the figure is caused by the change in the water content and ionic strength. In the $\mathrm{pH}$ range of 4.0-6.0, the calculated ALWC was in the highest range, increasing the contribution of $\mathrm{H}_{2} \mathrm{O}_{2}$ proportionally as calculated using Eq. (1).

Aerosol water content is another key factor that influences the contribution of different pathways to sulfate formation. In the calculation, we changed the unit of the sulfate formation rate from $\mu \mathrm{g} / \mathrm{m}^{3}$ of air to $\mathrm{M} / \mathrm{s}$ of water, and the sulfate formation rate can be calculated via the following equation with the modeled $\frac{\mathrm{dS}(\mathrm{VI})}{\mathrm{d} t}(\mathrm{M} / \mathrm{s})$ :

$$
\begin{aligned}
& \frac{\mathrm{dS}(\mathrm{VI})}{\mathrm{d} t}\left(\mu \mathrm{g} / \mathrm{m}^{3} / \mathrm{h}\right)=0.01 \times 3600(\mathrm{~s} / \mathrm{h}) \cdot 96 \mathrm{~g} / \mathrm{mol} \\
& . \frac{\mathrm{dS}(\mathrm{VI})}{\mathrm{d} t}(\mathrm{M} / \mathrm{s}) \cdot \frac{\mathrm{ALWC}}{\rho_{\text {water }}}
\end{aligned}
$$

where ALWC is in units of $\mu \mathrm{g} / \mathrm{m}^{3}$ and $\rho_{\text {water }}$ is the water density in $\mathrm{kg} / \mathrm{L}$. At high ionic strength, this expression is more accurate than the equivalent expression with the unit of $\mathrm{M} / \mathrm{s}$. The equilibrium amount of $\mathrm{H}_{2} \mathrm{O}_{2}, \mathrm{O}_{3}$ and $\mathrm{NO}_{2}$ in units of $\mu \mathrm{g} / \mathrm{m}^{3}$ of air is controlled by the amount of ALWC; i.e., there is equilibrium between gas and particle water for these oxidants formed in the gas phase. And the total quantity of metal elements, $\mathrm{Fe}, \mathrm{Cu}$ or $\mathrm{Mn}$ is not dependent on aerosol 

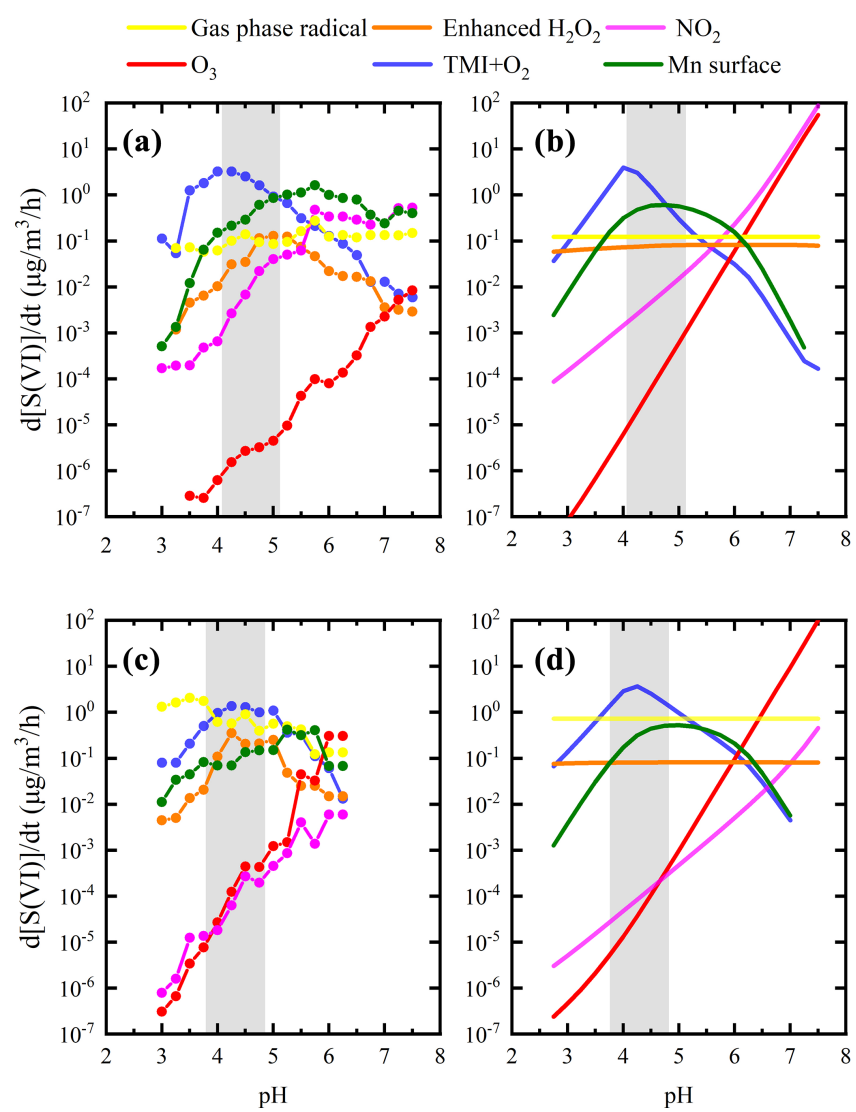

Figure 2. Multiphase sulfate production under actual ambient conditions (a, c) and averaged conditions $(\mathbf{b}, \mathbf{d})$ in winter $(\mathbf{a}, \mathbf{b})$ and summer (c, d) in the North China Plain. Given the actual measured concentration, the steady-state concentration of each reactant was calculated using the PKU-MARK model, accounting for the impact of ionic strength on the Henry's law coefficient of the gas-phase reactants. Panels (a) and (c) show the cluster-averaged results with a $\mathrm{pH}$ span of 0.5 . Panels (b) and (d) show the sulfate formation rate obtained by fixing the average precursors levels during the haze periods and by changing the aerosol $\mathrm{pH}$, which is consistent with the calculation method of previous studies (Cheng et al., 2016). Greyshaded areas indicate the ISORROPIA II (Fountoukis and Nenes, 2007) model calculated $\mathrm{pH}$ ranges during the haze periods of two field campaigns. The solid colored lines represent sulfate production rates calculated for different multiphase reaction pathways with oxidants: enhanced $\mathrm{H}_{2} \mathrm{O}_{2}, \mathrm{O}_{3}$, TMIs, $\mathrm{NO}_{2}$, surface $\mathrm{Mn}$ and gas-phase radicals $(\mathrm{OH}+\mathrm{SCIs})$. The solid orange line represents the calculated sulfate formation rate via $\mathrm{H}_{2} \mathrm{O}_{2}$ with a factor of 100 in winter and summer according to the latest research results (T. Liu et al., 2020). Reactant concentrations, aqueous reaction rate expressions and rate coefficients are summarized in the Supplement.

water content. Aerosol water content does not affect TMI levels in solution by affecting the solubility of the overall metal form of the specific species (Fig. 3 shows insensitivity of $\mathrm{pH}$ to ALWC, which has been pointed out in other papers ; Wong et al., 2020). The reaction kinetics and rate constants summarized in Table S2 suggest that there is a proportional relation- ship between ALWC and sulfate formation pathways except the aqTMI. One reason for the lower sulfate formation rate observed in PKU-17 $\left(1-3 \mu \mathrm{g} / \mathrm{m}^{3} / \mathrm{h}\right)$ is that the ALWC values were lower than those assumed in previous studies (ALWC = $300 \mu \mathrm{g} / \mathrm{m}^{3} / \mathrm{h}$ ). This deviation from the ALWC significantly reduces the contribution of several other pathways but not the contribution of transition metals to sulfate formation.

Due to the obvious heterogeneous reaction's contribution to sulfate formation in winter, we evaluated the influence of ALWC on sulfate formation pathways in winter. TMI-relevant pathways including the aqTMI and Mn-surface pathway were dominant in all ranges of ALWC as illustrated in Fig. 3. In the PKU-17 field campaign, with the increasing of ALWC from 1 to $150 \mu \mathrm{g} / \mathrm{m}^{3}$, the ratio of $\mathrm{Mn}$ surface / the aqTMI continuously decreased mainly because of the decreasing particle-specific surface areas. Mn-surface contributed most in the lower ALWC range where particlespecific surface area was high and provided more reaction positions. Aqueous transition metal ion molar concentration decreased with the aerosol hygroscopic growth, indicating a "dilution effect" as shown in Fig. S7 with the aerosol hygroscopic growth; the increase in transition metal total mass in air is slower than that in water mass in PKU-17. The ratio of $\mathrm{Fe}$ total mass $\left(\mathrm{Fe}_{\mathrm{t}}\right) / \mathrm{ALWC}$ decreased with $\mathrm{PM}_{2.5}$ mass. Previous global-scale observations (Sholkovitz et al., 2012) of $\sim 1100$ samples also showed the hyperbolic trends of Fe solubility with total Fe mass. Higher activity coefficients and lower aqueous TMI concentration led to the emergence of a "high platform" of the aqTMI contribution to sulfate formation in the range of $50-150 \mu \mathrm{g} / \mathrm{m}^{3}$ of ALWC (i.e., higher effective aqueous TMIs in this range). While ALWC exceeded $150 \mu \mathrm{g} / \mathrm{m}^{3}$ in winter, the increase in activity coefficients could not promote the rate of the aqTMI. Due to the slight increase in aerosol $\mathrm{pH}$ and the dilution effect of aerosol hygroscopic growth on TMIs when ALWC exceeded $150 \mu \mathrm{g} / \mathrm{m}^{3}$ as discussed above, the importance of aqTMI and $\mathrm{Mn}$-surface contributions were lowered. At this time, the contributions of external oxidizing substance pathways such as $\mathrm{H}_{2} \mathrm{O}_{2}, \mathrm{NO}_{2}$ or $\mathrm{O}_{3}$ may rise in the proper $\mathrm{pH}$ range as illustrated in Fig. 4. In winter fog or cloud conditions with higher water content, the contribution from TMIs may decrease a lot because of their low concentrations.

The same analysis is also used in the summer WD-14 field campaign (as shown in Fig. S8). The dilution effect occurred more dramatically in summer compared to in winter because of a higher RH and higher percentage of water in the aerosol. In this situation, the contribution of the aqTMI or Mn-surface was inhibited due to the low soluble TMI concentrations. Considering the positive relationships of the SOR and RH in the summer WD-14 field campaign, aqueous and surface sulfate formation contributions mentioned in the study could not explain the missing source of secondary sulfate. Because of the low $\mathrm{pH}$ range observed in the WD-14 field campaign, the contributions from $\mathrm{H}_{2} \mathrm{O}_{2}, \mathrm{NO}_{2}, \mathrm{O}_{3}$ or $\mathrm{NO}_{3}^{-}$photolysis were negligible. The missing contribution may mainly come from 

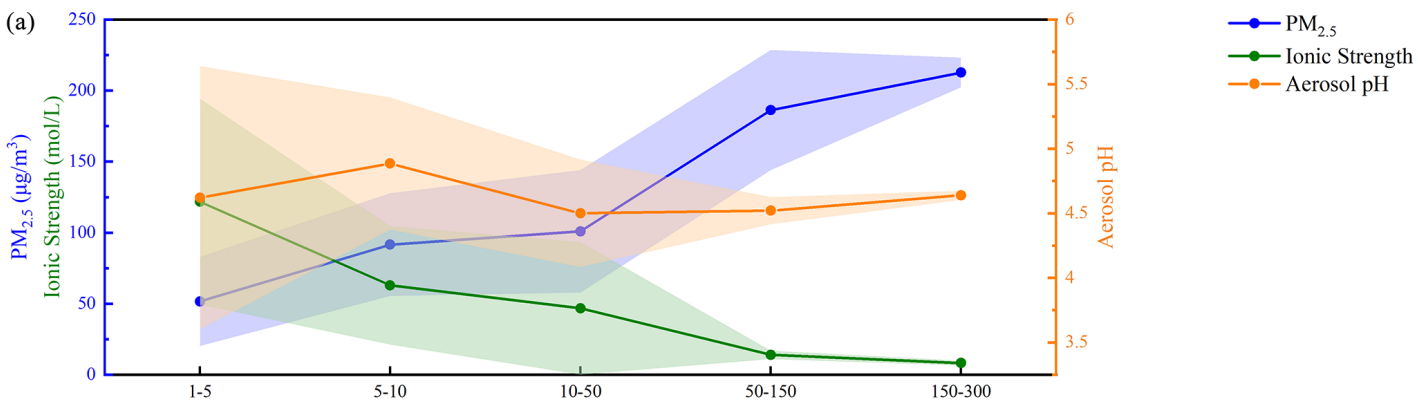

(b)

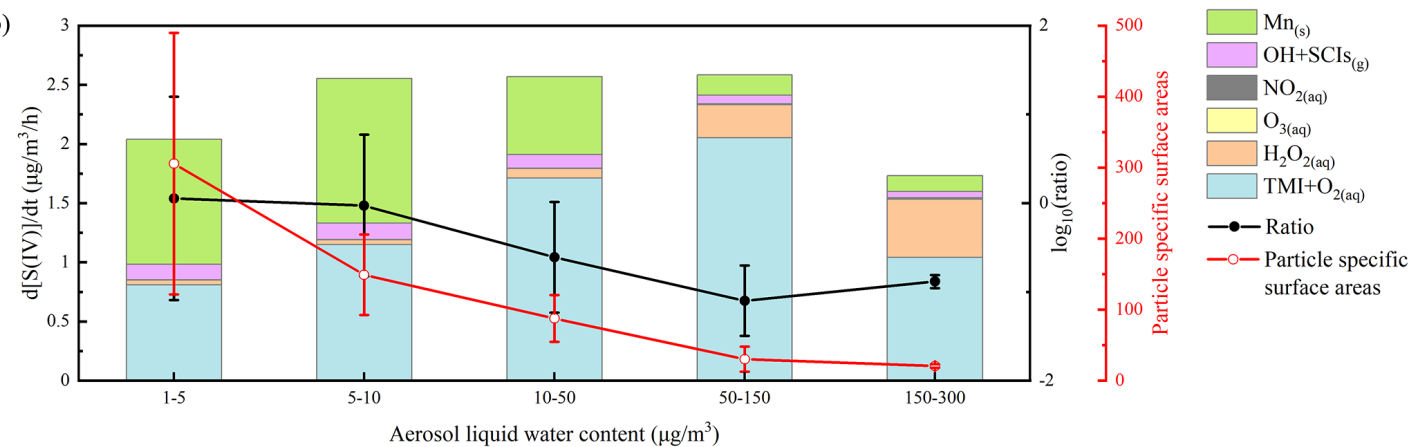

Figure 3. Variation in $\mathrm{PM}_{2.5}$, ionic strength, aerosol $\mathrm{pH}$, particle-specific surface areas and sulfate formation rates from different pathways with aerosol liquid water content (ALWC) during the winter field campaign. The total number of valid data points shown in the figure is 479. The shaded area refers to the error bar $( \pm 1 \sigma)$ of $\mathrm{PM}_{2.5}$ mass concentration, aerosol ionic strength and pH calculated by ISORROPIA II (Fountoukis and Nenes, 2007). The ratio in (b) refers to the ratio of contributions from Mn-surface to the aqTMI to produce sulfate. Particlespecific surface areas represent the ratio of particle surface area $\left(\mu \mathrm{m}^{2} / \mathrm{cm}^{3}\right)$ to mass concentration $\left(\mu \mathrm{g} / \mathrm{m}^{3}\right)$.

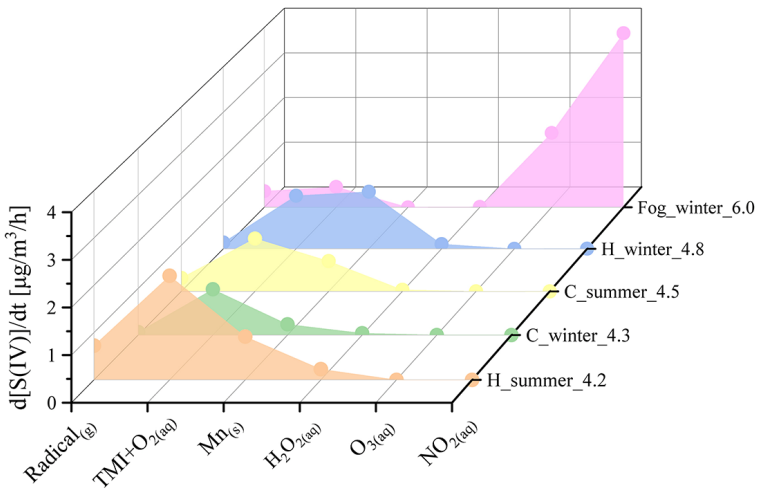

(a)

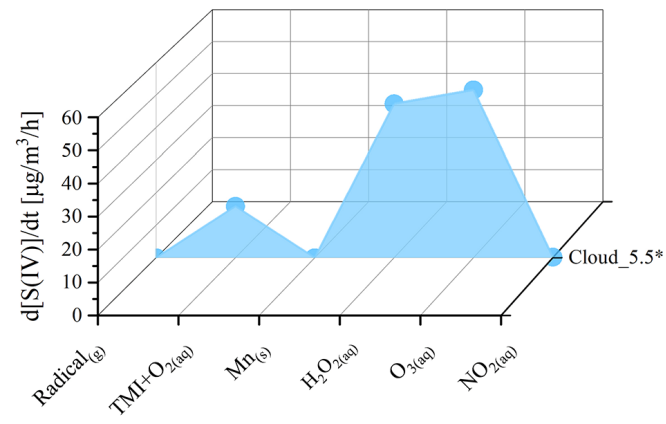

(b)

Figure 4. Graph showing modeled contributions of various pathways to sulfate formation under different pollution conditions. Different pollution conditions including clear $\left(\mathrm{PM}_{2.5}\right.$ smaller than $\left.35 \mu \mathrm{g} / \mathrm{m}^{3}\right)$ in the winter PKU-17 campaign (C_winter_4.3) and summer WD-14 campaign (C_summer_4.5), pollution $\left(\mathrm{PM}_{2.5}\right.$ larger than $\left.75 \mu \mathrm{g} / \mathrm{m}^{3}\right)$ in PKU-17 (H_winter_4.8) and WD-14 (H_summer_4.2), fog conditions used in a previous study (Xue et al., 2016) (Fog_winter_6.0), and cloud conditions (Cloud_5.5) simulated by Seinfeld and Pandis (2016). The number on each label indicates the average $\mathrm{pH}$ value chosen in these calculations. We assumed that the cloud water content is $0.1 \mathrm{~g} / \mathrm{m}^{3}$ in the last condition (Cloud_5.5) and reduced the $\mathrm{H}_{2} \mathrm{O}_{2}$ concentration to $0.1 \mathrm{ppb}$ compared to the high value used before (Seinfeld and Pandis, 2016).

other pathways such as photosensitizing molecules (Wang et al., 2020) under stronger UV in summer or contributions from hydroxy methane sulfonate (Moch et al., 2018; Ma et al., 2020) which need further studies.

\section{Discussion and conclusion}

We evaluated the contribution of different pathways to secondary sulfate formation using a state-of-the-art sizesegregated multiphase model constrained to the observed parameters from two field campaigns in the North China Plain. 
In addition, the effects of aerosol solution non-ideality on aqueous-phase reaction rates as well as dissolution equilibriums were considered in the calculations. The results indicated that the aqueous TMI-catalyzed oxidation pathway (aqTMI) was an important contributor to sulfate formation during haze episodes, which is consistent with the results of the isotope and WRF-Chem studies (He et al., 2018; Shao et al., 2019; Li et al., 2020a; Yue et al., 2020).

Despite the dominant role of the aqTMI in the PKU-17 field campaign, contributions from other multiphase pathways are not negligible. Dominant pathways varied with conditions such as clear or haze periods in clouds or aerosol water. Figure 4 exhibits the contribution of different oxidation pathways to sulfate formation in aerosol water (under different pollution levels), fog and clouds to indicate the dominant factors of sulfate formation under different conditions. In clear periods, gas-phase oxidation of $\mathrm{SO}_{2}$ by gas-phase radicals ( $\mathrm{OH}$ and SCIs) happens continuously, contributing $0.01-$ $0.6 \mu \mathrm{g} / \mathrm{m}^{3} / \mathrm{h}$ to sulfate formation. At the clean time, sulfate production is mainly limited by relatively low $\mathrm{SO}_{2}$ concentrations and low ALWC, which has promotion effects on the multiphase sulfate formation pathways. The average sulfate formation rate during clear days was $1.30 \mu \mathrm{g} / \mathrm{m}^{3} / \mathrm{h}$ in winter and $2.13 \mu \mathrm{g} / \mathrm{m}^{3} / \mathrm{h}$ in summer because of the generally higher ALWC in summer aerosols and much higher gas-phase radical concentrations. Gas-phase radicals (OH and SCIs) continuously oxidize $\mathrm{SO}_{2}$ during haze and clear periods.

External oxidizing substances such as $\mathrm{NO}_{2}$ and $\mathrm{O}_{3}$ made little contribution to sulfate formation during these haze periods because of the high aerosol acidity. High $\mathrm{pH}$ (near 7) values were observed in these field campaigns when the contribution of the $\mathrm{NO}_{2}$ pathway was dominant at some point but not during the entire pollution process; its proportion was much lower than that of the aqTMI. Although the enhancement factor of $\mathrm{H}_{2} \mathrm{O}_{2}$ oxidation was considered based on the measurement of a previous study ( $\mathrm{T}$. Liu et al., 2020), the contribution of $\mathrm{H}_{2} \mathrm{O}_{2}$ oxidation was still below $0.5 \mu \mathrm{g} \mathrm{S}(\mathrm{VI}) / \mathrm{m}^{3} / \mathrm{h}$ because ALWC was about 10 times lower than $300 \mu \mathrm{g} / \mathrm{m}^{3}$, which was used in previous studies (Cheng et al., 2016; T. Liu et al., 2020).

The sulfate formation rate is limited by the ALWC according to Eq. (1). Aerosol particles have lower water content than cloud droplets, which provides larger space for aqueousphase reactions. Therefore, at the gas-phase $\mathrm{SO}_{2}$ concentrations of 5-50 ppb, 10-100-times-higher water content in fog and cloud droplets can cause higher sulfate formation rates of up to $100 \mu \mathrm{g} / \mathrm{m}^{3} / \mathrm{h}$ assuming $0.1 \mathrm{~g} / \mathrm{m}^{3}$ water in clouds (Fig. 4). A high $\mathrm{H}_{2} \mathrm{O}_{2}$ concentration (1 ppb), which was 50 times higher than that in the PKU field campaign, was used in the calculation in the Cloud_5.0 regime (Seinfeld and Pandis, 2016). No obvious contribution from the $\mathrm{NO}_{2}$ oxidation pathway was observed in the PKU-17 and WD-14 field campaigns because of the lower $\mathrm{pH}$ range. As proposed in a previous study, particulate nitrate photolysis can explain the missing source of sulfate in Beijing haze (Zheng et al., 2020).
However, according to a recent laboratory report (Shi et al., 2021), the nitrate photolysis enhancement factor is no larger than 2 at all RH ranges. We also included the calculation of nitrate photolysis in this study due to the high loading of particle nitrate and found that the contribution was rather small ( $\sim 0.008 \mu \mathrm{g} / \mathrm{m}^{3} / \mathrm{h}$ in winter haze periods); thus, we did not include this pathway in the figures.

According to our modeled results and a new study (Wang et al., 2021), Mn surface reactions contribute a lot to sulfate formation. Except for possible $\mathrm{Mn}(\mathrm{OH})_{x}^{(3-x)}$ reacting with $\mathrm{SO}_{2}$, Zhang et al. (2006) proposed that other metal oxides such as $\mathrm{Fe}_{2} \mathrm{O}_{3}$ and $\mathrm{Al}_{2} \mathrm{O}_{3}$ can also react with $\mathrm{SO}_{2}$ on the surface of particles. The ratio of contributions from $\mathrm{Mn}$ surface / the aqTMI to produce sulfate will decrease with aerosol hygroscopic growth owing to higher ALWC and lower specific surface areas (as shown in Fig. 3b, dotted black line). What is more, the organic coating of aerosol particles can largely reduce the reactivity of surface heterogeneous reactions (Zelenov et al., 2017; Anttila et al., 2006; Folkers et al., 2003; Ryder et al., 2015) and may cause the Mn-surface pathway to be less important. High mass concentrations of organic aerosols (OAs) were observed in Beijing in both winter and summer (Hu et al., 2016). Based on the measured result (Yu et al., 2019) from transmission electron microscopy, up to $74 \%$ of non-sea-salt sulfate particles were coated with organic matter $(\mathrm{OM})$. The organic coating can effectively reduce the reactive sites on the surface of particles and hence reduce the reaction probability of $\mathrm{SO}_{2}$ with surface metal. On the other hand, the widespread presence of aerosol organic coating can also influence the bulk $\mathrm{SO}_{2}$ catalyzed by aqueous TMIs and not only the surface reactions. This effect is mainly achieved by the change in $\mathrm{SO}_{2}$ solubility and diffusion coefficient rather than the rates of catalytic reactions with TMIs. Although the solubility of $\mathrm{SO}_{2}$ in organic solvent changes a lot with the component of organic matter (Zhang et al., 2013; K. Huang et al., 2014), according to previous studies of the $\mathrm{SO}_{2}$ uptake coefficient with sea-salt aerosols (Gebel et al., 2000) and secondary organic aerosols (SOAs) (Yao et al., 2019), no obvious uptake coefficient reduction was observed, with the organic coating further proving the minor influence of the organic coating on bulk reaction rates. The catalytic reaction of $\mathrm{SO}_{2}$ with the aqTMI may be less affected by aerosol organic coating compared to $\mathrm{SO}_{2}$ with $\mathrm{Mn}$-surface. For these reasons, the surface reaction of $\mathrm{SO}_{2}$ with $\mathrm{Mn}$ and other metals in actual aerosol conditions remains unclear with high uncertainties and needs further evaluation. The relevant calculation results of WD-14 and PKU17 in this paper represent the upper limit of the Mn-surface contribution. The missing contribution in WD-14 polluted conditions may mainly come from organic photosensitizing molecules such as HULIS (Wang et al., 2020) under stronger UV in summer or other SOA coupled mechanisms.

The results in this paper indicate that sulfate formation has different chemical behaviors in different conditions. Aqueous TMI-catalyzed oxidation was the most important path- 
way followed by the surface oxidation of $\mathrm{Mn}$ in both winter and summer, while the hydroxyl and Criegee radical oxidations contribute significantly in summer. Due to the differences in the physical and chemical properties between aerosol water, fog water and cloud, nitrogen dioxide oxidation is the dominant pathway in higher $\mathrm{pH}$ ranges and hydroperoxide and ozone oxidations dominated for the cloud. In model studies, the averaged and fixed values should be used dialectically and carefully in the calculation of the sulfate formation rate because of the mutual restriction between factors such as $\mathrm{pH}$, effective ion activity and concentration, and aerosol water content. Model evaluation or numerical calculations of secondary pollutants should focus on the application of actual atmospheric conditions observed in field campaigns with the application of closure studies. Our results highlight the important role of the aerosol aqTMI in sulfate formation during haze periods, and the monitoring network of aerosol metal is necessary for the studies of secondary sulfate formation. The aqTMI independent of solar radiation also explains the explosive growth of sulfate production in the nighttime, which is frequently observed during haze episodes in the NCP.

Compared to the gas-phase oxidants, the control of anthropogenic emissions of aerosol TMIs is conducive to a reduction in secondary sulfates. The promotion of clean-energy strategies aiming at reducing coal burning and vehicle emissions to improve air quality in North China has reduced not only the primary emissions of $\mathrm{SO}_{2}$ but also the anthropogenic emissions of aerosol TMIs (Liu et al., 2018) and thus the production of secondary sulfate. What is more, China's ecological and environmental protection measures for tree planting and afforestation are conducive to reducing the generation of dust especially in the spring, further reducing the quality of metal $\mathrm{Fe}$ concentrations in aerosols.

Our findings showed that urban aerosol TMIs contribute to sulfate formation during haze episodes and play a key role in developing mitigation strategies and public health measures in megacities worldwide, but the physicochemical processes of transition metals in particles require further research. Dissolved Mn concentrations in this study were estimated based on previous studies. The solubility of transition metals in aerosol water varying largely due to several factors including various source emissions, aerosol organic matter and $\mathrm{pH}$ (Paris and Desboeufs, 2013; Wozniak et al., 2015; Tapparo et al., 2020) was fully considered in this study. Influences of organic matter and photosensitizing molecules on the solubility of transition metal and the mechanism of sulfate formation need further research to understand this complex and dynamic multiphase process from a broader perspective.

Data availability. Data supporting this publication are available upon request from the corresponding author (k.lu@pku.edu.cn).
Supplement. The supplement related to this article is available online at: https://doi.org/10.5194/acp-21-13713-2021-supplement.

Author contributions. KL conceived the study. HS and KL developed the PKU-MARK model for multiphase simulations. CY provided support in calculations. HS performed the model simulations and wrote the manuscript with KL and CY. KL and YZ led the two field campaigns. KL, HD, SL, SC, ZW, MZ, LZ, MH and YZ provided campaign data for the analysis.

Competing interests. The contact author has declared that neither they nor their co-authors have any competing interests.

Disclaimer. Publisher's note: Copernicus Publications remains neutral with regard to jurisdictional claims in published maps and institutional affiliations.

Acknowledgements. We gratefully acknowledge the comprehensive observation of the science teams of the Wangdu and PKU field campaigns.

Financial support. This research has been supported by the Data Center of Management Science, National Natural Science Foundation of China - Peking University (grant no. 21976006), the National Key Research and Development Program of China (grant no. 2019YFC0214800), the National Key Research Program for Air Pollution Control (DQGG202002), and the Beijing Municipal Natural Science Foundation (grant no. JQ19031).

Review statement. This paper was edited by Qiang Zhang and reviewed by two anonymous referees.

\section{References}

Alexander, B., Park, R. J., Jacob, D. J., and Gong, S.: Transition metal-catalyzed oxidation of atmospheric sulfur: Global implications for the sulfur budget, J. Geophys. Res.-Atmos., 114, D02309, https://doi.org/10.1029/2008JD010486, 2009.

Anttila, T., Kiendler-Scharr, A., Tillmann, R., and Mentel, T. F.: On the Reactive Uptake of Gaseous Compounds by OrganicCoated Aqueous Aerosols: Theoretical Analysis and Application to the Heterogeneous Hydrolysis of $\mathrm{N}_{2} \mathrm{O}_{5}$, J. Phys. Chem. A, 110, 10435-10443, doi10.1021/jp062403c, 2006.

Atkinson, R., Baulch, D. L., Cox, R. A., Crowley, J. N., Hampson, R. F., Hynes, R. G., Jenkin, M. E., Rossi, M. J., and Troe, J.: Evaluated kinetic and photochemical data for atmospheric chemistry: Volume $\mathrm{I}-$ gas phase reactions of $\mathrm{O}_{x}, \mathrm{HO}_{x}$, $\mathrm{NO}_{x}$ and $\mathrm{SO}_{x}$ species, Atmos. Chem. Phys., 4, 1461-1738, https://doi.org/10.5194/acp-4-1461-2004, 2004. 
Baker, A. R. and Jickells, T. D.: Mineral particle size as a control on aerosol iron solubility, Geophys. Res. Lett., 33, L17608, https://doi.org/10.1029/2006g1026557, 2006.

Baker, A. R., Jickells, T. D., Witt, M., and Linge, K. L.: Trends in the solubility of iron, aluminium, manganese and phosphorus in aerosol collected over the Atlantic Ocean, Mar. Chem., 98, 4358, https://doi.org/10.1016/j.marchem.2005.06.004, 2006.

Barth, M. C., Hess, P. G., and Madronich, S.: Effect of marine boundary layer clouds on tropospheric chemistry as analyzed in a regional chemistry transport model, J. Geophys. Res.-Atmos., 107, AAC 7-1-AAC 7-12, https://doi.org/10.1029/2001JD000468, 2002.

Bian, Y. X., Zhao, C. S., Ma, N., Chen, J., and Xu, W. Y.: A study of aerosol liquid water content based on hygroscopicity measurements at high relative humidity in the North China Plain, Atmos. Chem. Phys., 14, 6417-6426, https://doi.org/10.5194/acp14-6417-2014, 2014.

Chameides, W. and Stelson, A.: Aqueous-phase chemical processes in deliquescent sea-salt aerosols: A mechanism that couples the atmospheric cycles of S and sea salt, J. Geophys. Res.-Atmos., 97, 20565-20580, 1992a.

Chameides, W. L. and Stelson, A. W.: Aqueous-phase chemical processes in deliquescent seasalt aerosols, Ber. Bunsen Phys. Chem., 96, 461-470, 1992b.

Cheng, Y., Zheng, G., Wei, C., Mu, Q., Zheng, B., Wang, Z., Gao, M., Zhang, Q., He, K., Carmichael, G., Pöschl, U., and Su, H.: Reactive nitrogen chemistry in aerosol water as a source of sulfate during haze events in China, Sci. Adv., 2, e1601530, https://doi.org/10.1126/sciadv.1601530, 2016.

Duan, J. C., Tan, J. H., Wang, S. L., Hao, J. M., and Chail, F. H.: Size distributions and sources of elements in particulate matter at curbside, urban and rural sites in Beijing, J. Environ. Sci., 24, 87-94, https://doi.org/10.1016/s1001-0742(11)60731-6, 2012.

Fang, T., Guo, H., Zeng, L., Verma, V., Nenes, A., and Weber, R. J.: Highly Acidic Ambient Particles, Soluble Metals, and Oxidative Potential: A Link between Sulfate and Aerosol Toxicity, Environ. Sci. Technol., 51, 2611-2620, https://doi.org/10.1021/acs.est.6b06151, 2017.

Folkers, M., Mentel, T. F., and Wahner, A.: Influence of an organic coating on the reactivity of aqueous aerosols probed by the heterogeneous hydrolysis of $\mathrm{N}_{2} \mathrm{O}_{5}$, Geophys. Res. Lett., 30, 12, https://doi.org/10.1029/2003GL017168, 2003.

Fountoukis, C. and Nenes, A.: ISORROPIA II: a computationally efficient thermodynamic equilibrium model for $\mathrm{K}^{+}-$ $\mathrm{Ca}^{2+}-\mathrm{Mg}^{2+}-\mathrm{NH}_{4}^{+}-\mathrm{Na}^{+}-\mathrm{SO}_{4}^{2-}-\mathrm{NO}_{3}^{-}-\mathrm{Cl}^{-}-\mathrm{H}_{2} \mathrm{O}$ aerosols, Atmos. Chem. Phys., 7, 4639-4659, https://doi.org/10.5194/acp-74639-2007, 2007.

Gao, J., Peng, X., Chen, G., Xu, J., Shi, G.-L., Zhang, Y.-C., and Feng, Y.-C.: Insights into the chemical characterization and sources of $\mathrm{PM}_{2.5}$ in Beijing at a 1-h time resolution, Sci. Total Environ., 542, 162-171, 2016.

Gebel, M. E., Finlayson-Pitts, B. J., and Ganske, J. A.: The uptake of $\mathrm{SO}_{2}$ on synthetic sea salt and some of its components, Geophys. Res. Lett., 27, 887-890, https://doi.org/10.1029/1999GL011152, 2000.

Goliff, W. S. and Stockwell, W. R.: The Regional Atmospheric Chemistry Mechanism, Version 2, an Update, in: Proceedings of the International Conference on Atmospheric Chemical Mecha- nisms, University of California, Davis, CA, USA, 8-10 December 2008, University of California, Davis, CA, USA, 2008.

Goliff, W. S., Stockwell, W. R., and Lawson, C. V.: The regional atmospheric chemistry mechanism, version 2, Atmos. Environ., 68, 174-185, 2013.

Guo, H., Weber, R. J., and Nenes, A.: High levels of ammonia do not raise fine particle $\mathrm{pH}$ sufficiently to yield nitrogen oxide-dominated sulfate production, Sci. Rep.-UK, 7, 12109, https://doi.org/10.1038/s41598-017-11704-0, 2017.

Guo, H., Xu, L., Bougiatioti, A., Cerully, K. M., Capps, S. L., Hite Jr., J. R., Carlton, A. G., Lee, S.-H., Bergin, M. H., Ng, N. L., Nenes, A., and Weber, R. J.: Fine-particle water and $\mathrm{pH}$ in the southeastern United States, Atmos. Chem. Phys., 15, 5211-5228, https://doi.org/10.5194/acp-15-5211-2015, 2015.

Guo, S., Hu, M., Zamora, M. L., Peng, J. F., Shang, D. J., Zheng, J., Du, Z. F., Wu, Z., Shao, M., Zeng, L. M., Molina, M. J., and Zhang, R. Y.: Elucidating severe urban haze formation in China, P. Natl. Acad. Sci. USA, 111, 17373-17378, https://doi.org/10.1073/pnas.1419604111, 2014.

Hanson, D. R., Ravishankara, A. R., and Solomon, S.: Heterogeneous reactions in sulfuric-acid aerosol: A framework for model calculations, J. Geophys. Res.-Atmos., 99, 3615-3629, https://doi.org/10.1029/93jd02932, 1994.

He, P., Alexander, B., Geng, L., Chi, X., Fan, S., Zhan, H., Kang, H., Zheng, G., Cheng, Y., Su, H., Liu, C., and Xie, Z.: Isotopic constraints on heterogeneous sulfate production in Beijing haze, Atmos. Chem. Phys., 18, 5515-5528, https://doi.org/10.5194/acp18-5515-2018, 2018.

Heal, M. R., Hibbs, L. R., Agius, R. M., and Beverland, L. J.: Total and water-soluble trace metal content of urban background $\mathrm{PM}_{10}, \mathrm{PM}_{2.5}$ and black smoke in Edinburgh, UK, Atmos. Environ., 39, 1417-1430, https://doi.org/10.1016/j.atmosenv.2004.11.026, 2005.

Hsu, S.-C., Wong, G. T. F., Gong, G.-C., Shiah, F.-K., Huang, Y.-T., Kao, S.-J., Tsai, F., Candice Lung, S.-C., Lin, F.-J., Lin, I. I., Hung, C.-C., and Tseng, C.-M.: Sources, solubility, and dry deposition of aerosol trace elements over the East China Sea, Mar. Chem., 120, 116-127, https://doi.org/10.1016/j.marchem.2008.10.003, 2010.

Hu, W., Hu, M., Hu, W., Jimenez, J. L., Yuan, B., Chen, W., Wang, M., Wu, Y., Chen, C., Wang, Z., Peng, J., Zeng, L., and Shao, M.: Chemical composition, sources, and aging process of submicron aerosols in Beijing: Contrast between summer and winter, J. Geophys. Res.-Atmos., 121, 1955-1977, https://doi.org/10.1002/2015JD024020, 2016.

Huang, K., Xia, S., Zhang, X.-M., Chen, Y.-L., Wu, Y.-T., and $\mathrm{Hu}, \mathrm{X} .-\mathrm{B} .:$ Comparative Study of the Solubilities of $\mathrm{SO}_{2}$ in Five Low Volatile Organic Solvents (Sulfolane, Ethylene Glycol, Propylene Carbonate, N-Methylimidazole, and N-Methylpyrrolidone), J. Chem. Eng. Data, 59, 1202-1212, https://doi.org/10.1021/je4007713, 2014.

Huang, R.-J., Zhang, Y., Bozzetti, C., Ho, K.-F., Cao, J.-J., Han, Y., Daellenbach, K. R., Slowik, J. G., Platt, S. M., Canonaco, F., Zotter, P., Wolf, R., Pieber, S. M., Bruns, E. A., Crippa, M., Ciarelli, G., Piazzalunga, A., Schwikowski, M., Abbaszade, G., SchnelleKreis, J., Zimmermann, R., An, Z., Szidat, S., Baltensperger, U., Haddad, I. E., and Prévôt, A. S. H.: High secondary aerosol contribution to particulate pollution during haze events in China, Nature, 514, 218-222, 10.1038/nature13774, 2014. 
Huang, X., Song, Y., Zhao, C., Li, M., Zhu, T., Zhang, Q., and Zhang, X.: Pathways of sulfate enhancement by natural and anthropogenic mineral aerosols in China, J. Geophys. Res.-Atmos., 119, 14165-14179, https://doi.org/10.1002/2014JD022301, 2014.

Ito, A., Myriokefalitakis, S., Kanakidou, M., Mahowald, N. M., Scanza, R. A., Hamilton, D. S., Baker, A. R., Jickells, T., Sarin, M., Bikkina, S., Gao, Y., Shelley, R. U., Buck, C. S., Landing, W. M., Bowie, A. R., Perron, M. M. G., Guieu, C., Meskhidze, N., Johnson, M. S., Feng, Y., Kok, J. F., Nenes, A., and Duce, R. A.: Pyrogenic iron: The missing link to high iron solubility in aerosols, Sci. Adv., 5, eaau7671, https://doi.org/10.1126/sciadv.aau7671, 2019.

Koop, T., Luo, B., Tsias, A., and Peter, T.: Water activity as the determinant for homogeneous ice nucleation in aqueous solutions, Nature, 406, 611-614, 2000.

Lelieveld, J. and Crutzen, P. J.: The role of clouds in tropospheric photochemistry, J. Atmos. Chem., 12, 229-267, https://doi.org/10.1007/bf00048075, 1991.

Li, J., Zhang, Y.-L., Cao, F., Zhang, W., Fan, M., Lee, X., and Michalski, G.: Stable Sulfur Isotopes Revealed a Major Role of Transition-Metal Ion-Catalyzed $\mathrm{SO}_{2}$ Oxidation in Haze Episodes, Environ. Sci. Technol., 54, 2626-2634, https://doi.org/10.1021/acs.est.9b07150, 2020a.

Li, J., Zhu, C., Chen, H., Fu, H., Xiao, H., Wang, X., Herrmann, H., and Chen, J.: A More Important Role for the Ozone-S(IV) Oxidation Pathway Due to Decreasing Acidity in Clouds, J. Geophys. Res.-Atmos., 125, e2020JD033220, https://doi.org/10.1029/2020JD033220, 2020b.

Li, L., Hoffmann, M. R., and Colussi, A. J.: Role of Nitrogen Dioxide in the Production of Sulfate during Chinese Haze-Aerosol Episodes, Environ. Sci. Technol., 52, 2686-2693, https://doi.org/10.1021/acs.est.7b05222, 2018.

Lippmann, M. and Thurston, G. D.: Sulfate concentrations as an indicator of ambient particulate matter air pollution for health risk evaluations, J. Expo. Anal. Environ. Epidemiol., 6, 123-146, 1996.

Liu, C., Ma, Q., Liu, Y., Ma, J., and He, H.: Synergistic reaction between $\mathrm{SO}_{2}$ and $\mathrm{NO}_{2}$ on mineral oxides: a potential formation pathway of sulfate aerosol, Phys. Chem. Chem. Phys., 14, 16681676, https://doi.org/10.1039/C1CP22217A, 2012.

Liu, J., Chen, Y., Chao, S., Cao, H., Zhang, A., and Yang, Y.: Emission control priority of $\mathrm{PM}_{2.5}$-bound heavy metals in different seasons: A comprehensive analysis from health risk perspective, Sci. Total Environ., 644, 20-30, https://doi.org/10.1016/j.scitotenv.2018.06.226, 2018.

Liu, M., Song, Y., Zhou, T., Xu, Z., Yan, C., Zheng, M., Wu, Z., $\mathrm{Hu}, \mathrm{M}$., Wu, Y., and Zhu, T.: Fine particle pH during severe haze episodes in northern China, Geophys. Res. Lett., 44, 5213-5221, https://doi.org/10.1002/2017GL073210, 2017.

Liu, P., Ye, C., Xue, C., Zhang, C., Mu, Y., and Sun, X.: Formation mechanisms of atmospheric nitrate and sulfate during the winter haze pollution periods in Beijing: gas-phase, heterogeneous and aqueous-phase chemistry, Atmos. Chem. Phys., 20, 4153-4165, https://doi.org/10.5194/acp-20-4153-2020, 2020.

Liu, T., Clegg, S. L., and Abbatt, J. P. D.: Fast oxidation of sulfur dioxide by hydrogen peroxide in deliquesced aerosol particles, P. Natl. Acad. Sci. USA, 117, 1354-1359, https://doi.org/10.1073/pnas.1916401117, 2020.
Lou, M., Guo, J., Wang, L., Xu, H., Chen, D., Miao, Y., Lv, Y., Li, Y., Guo, X., Ma, S., and Li, J.: On the Relationship Between Aerosol and Boundary Layer Height in Summer in China Under Different Thermodynamic Conditions, Earth Space Sci., 6, 887901, https://doi.org/10.1029/2019EA000620, 2019.

Ma, T., Furutani, H., Duan, F., Kimoto, T., Jiang, J., Zhang, Q., Xu, X., Wang, Y., Gao, J., Geng, G., Li, M., Song, S., Ma, Y., Che, F., Wang, J., Zhu, L., Huang, T., Toyoda, M., and He, K.: Contribution of hydroxymethanesulfonate (HMS) to severe winter haze in the North China Plain, Atmos. Chem. Phys., 20, 5887-5897, https://doi.org/10.5194/acp-20-5887-2020, 2020.

Ma, X., Tan, Z., Lu, K., Yang, X., Liu, Y., Li, S., Li, X., Chen, S., Novelli, A., and Cho, C.: Winter photochemistry in Beijing: Observation and model simulation of $\mathrm{OH}$ and $\mathrm{HO}_{2}$ radicals at an urban site, Sci. Total Environ., 685, 85-95, 2019.

Mahowald, N. M., Baker, A. R., Bergametti, G., Brooks, N., Duce, R. A., Jickells, T. D., Kubilay, N., Prospero, J. M., and Tegen, I.: Atmospheric global dust cycle and iron inputs to the ocean, Global Biogeochem. Cy., 19, GB4025, https://doi.org/10.1029/2004GB002402, 2005.

Moch, J. M., Dovrou, E., Mickley, L. J., Keutsch, F. N., Cheng, Y., Jacob, D. J., Jiang, J., Li, M., Munger, J. W., and Qiao, X.: Contribution of hydroxymethane sulfonate to ambient particulate matter: A potential explanation for high particulate sulfur during severe winter haze in Beijing, Geophys. Res. Lett., 45, 1196911979, 2018.

Oakes, M., Rastogi, N., Majestic, B. J., Shafer, M., Schauer, J. J., Edgerton, E. S., and Weber, R. J.: Characterization of soluble iron in urban aerosols using near-real time data, J. Geophys. Res.Atmos., 115, D15302, https://doi.org/10.1029/2009JD012532, 2010.

Paris, R. and Desboeufs, K. V.: Effect of atmospheric organic complexation on iron-bearing dust solubility, Atmos. Chem. Phys., 13, 4895-4905, https://doi.org/10.5194/acp-134895-2013, 2013.

Petters, M. D. and Kreidenweis, S. M.: A single parameter representation of hygroscopic growth and cloud condensation nucleus activity, Atmos. Chem. Phys., 7, 1961-1971, https://doi.org/10.5194/acp-7-1961-2007, 2007.

Ross, H. B. and Noone, K. J.: A numerical investigation of the destruction of peroxy radical by cu ion catalyzed-reactions on atmospheric particles, J. Atmos. Chem., 12, 121-136, https://doi.org/10.1007/bf00115775, 1991.

Ryder, O. S., Campbell, N. R., Morris, H., Forestieri, S., Ruppel, M. J., Cappa, C., Tivanski, A., Prather, K., and Bertram, T. H.: Role of Organic Coatings in Regulating $\mathrm{N}_{2} \mathrm{O}_{5}$ Reactive Uptake to Sea Spray Aerosol, J. Phys. Chem. A, 119, 11683-11692, https://doi.org/10.1021/acs.jpca.5b08892, 2015.

Sander, R.: Modeling atmospheric chemistry: Interactions between gas-phase species and liquid cloud/aerosol particles, Surv. Geophys., 20, 1-31, 1999.

Sarwar, G., Godowitch, J., Fahey, K., Xing, J., Wong, D. C., Young, J., Roselle, S., and Mathur, R.: Examination of Sulfate production by CB05TU, RACM2 \& RACM2 with SCI initiated $\mathrm{SO}_{2}$,oxidation in the Northern Hemisphere, Presented at Presentation at the CMAS Conference, Chapel Hill, NC, 2013.

Schwartz, S. E.: Gas phase and aqueous phase chemistry of $\mathrm{HO}_{2}$ in liquid water clouds, J. Geophys. Res.-Atmos., 89, 1589-1598, https://doi.org/10.1029/JD089iD07p11589, 1984. 
Schwartz, S. E.: Mass-transport considerations pertinent to aqueous phase reactions of gases in liquid-water clouds, in: Chemistry of multiphase atmospheric systems, Springer, 415-471, 1986.

Seigneur, C. and Saxena, P.: A theoretical investigation of sulfate formation in clouds, Atmos. Environ., 22, 101-115, https://doi.org/10.1016/0004-6981(88)90303-4, 1988.

Seinfeld, J. H. and Pandis, S. N.: Atmospheric chemistry and physics: from air pollution to climate change, John Wiley \& Sons, 2016.

Shang, D., Peng, J., Guo, S., Wu, Z., and Hu, M.: Secondary aerosol formation in winter haze over the Beijing-TianjinHebei Region, China, Front. Environ. Sci. Eng., 15, 34, https://doi.org/10.1007/s11783-020-1326-x, 2020.

Shao, J., Chen, Q., Wang, Y., Lu, X., He, P., Sun, Y., Shah, V., Martin, R. V., Philip, S., Song, S., Zhao, Y., Xie, Z., Zhang, L., and Alexander, B.: Heterogeneous sulfate aerosol formation mechanisms during wintertime Chinese haze events: air quality model assessment using observations of sulfate oxygen isotopes in Beijing, Atmos. Chem. Phys., 19, 6107-6123, https://doi.org/10.5194/acp-19-6107-2019, 2019.

Shi, Q., Tao, Y., Krechmer, J. E., Heald, C. L., Murphy, J. G., Kroll, J. H., and Ye, Q.: Laboratory Investigation of Renoxification from the Photolysis of Inorganic Particulate Nitrate, Environ. Sci. Technol., 55, 854-861, https://doi.org/10.1021/acs.est.0c06049, 2021.

Shi, Z., Krom, M. D., Jickells, T. D., Bonneville, S., Carslaw, K. S., Mihalopoulos, N., Baker, A. R., and Benning, L. G.: Impacts on iron solubility in the mineral dust by processes in the source region and the atmosphere: A review, Aeolian Res., 5, 21-42, https://doi.org/10.1016/j.aeolia.2012.03.001, 2012.

Sholkovitz, E. R., Sedwick, P. N., Church, T. M., Baker, A. R., and Powell, C. F.: Fractional solubility of aerosol iron: Synthesis of a global-scale data set, Geochim. Cosmochim. Ac., 89, 173-189, https://doi.org/10.1016/j.gca.2012.04.022, 2012.

Song, H., Chen, X., Lu, K., Zou, Q., Tan, Z., Fuchs, H., Wiedensohler, A., Moon, D. R., Heard, D. E., Baeza-Romero, M.T., Zheng, M., Wahner, A., Kiendler-Scharr, A., and Zhang, Y.: Influence of aerosol copper on $\mathrm{HO}_{2}$ uptake: a novel parameterized equation, Atmos. Chem. Phys., 20, 15835-15850, https://doi.org/10.5194/acp-20-15835-2020, 2020.

Tan, Z., Fuchs, H., Lu, K., Hofzumahaus, A., Bohn, B., Broch, S., Dong, H., Gomm, S., Häseler, R., He, L., Holland, F., Li, X., Liu, Y., Lu, S., Rohrer, F., Shao, M., Wang, B., Wang, M., Wu, Y., Zeng, L., Zhang, Y., Wahner, A., and Zhang, Y.: Radical chemistry at a rural site (Wangdu) in the North China Plain: observation and model calculations of $\mathrm{OH}, \mathrm{HO}_{2}$ and $\mathrm{RO}_{2}$ radicals, Atmos. Chem. Phys., 17, 663-690, https://doi.org/10.5194/acp17-663-2017, 2017.

Tapparo, A., Di Marco, V., Badocco, D., D’Aronco, S., Sold, L., Pastore, P., Mahon, B. M., Kalberer, M., and Giorio, C.: Formation of metal-organic ligand complexes affects solubility of metals in airborne particles at an urban site in the Po valley, Chemosphere, 241, 125025, https://doi.org/10.1016/j.chemosphere.2019.125025, 2020.

Wang, G., Zhang, R., Gomez, M. E., Yang, L., Zamora, M. L., Hu, M., Lin, Y., Peng, J., Guo, S., Meng, J., Li, J., Cheng, C., Hu, T., Ren, Y., Wang, Y., Gao, J., Cao, J., An, Z., Zhou, W., Li, G., Wang, J., Tian, P., Marrero-Ortiz, W., Secrest, J., Du, Z., Zheng, J., Shang, D., Zeng, L., Shao, M., Wang, W., Huang, Y., Wang,
Y., Zhu, Y., Li, Y., Hu, J., Pan, B., Cai, L., Cheng, Y., Ji, Y., Zhang, F., Rosenfeld, D., Liss, P. S., Duce, R. A., Kolb, C. E., and Molina, M. J.: Persistent sulfate formation from London Fog to Chinese haze, P. Natl. Acad. Sci. USA, 113, 13630-13635, https://doi.org/10.1073/pnas.1616540113, 2016.

Wang, W., Liu, M., Wang, T., Song, Y., Zhou, L., Cao, J., Hu, J., Tang, G., Chen, Z., Li, Z., Xu, Z., Peng, C., Lian, C., Chen, Y., Pan, Y., Zhang, Y., Sun, Y., Li, W., Zhu, T., Tian, H., and Ge, M.: Sulfate formation is dominated by manganese-catalyzed oxidation of $\mathrm{SO}_{2}$ on aerosol surfaces during haze events, Nat. Commun., 12, 1993, 10.1038/s41467-021-22091-6, 2021.

Wang, X., Gemayel, R., Hayeck, N., Perrier, S., Charbonnel, N., Xu, C., Chen, H., Zhu, C., Zhang, L., Wang, L., Nizkorodov, S. A., Wang, X., Wang, Z., Wang, T., Mellouki, A., Riva, M., Chen, J., and George, C.: Atmospheric Photosensitization: A New Pathway for Sulfate Formation, Environ. Sci. Technol., 54, 3114 3120, https://doi.org/10.1021/acs.est.9b06347, 2020.

Weber, R. J., Guo, H., Russell, A. G., and Nenes, A.: High aerosol acidity despite declining atmospheric sulfate concentrations over the past 15 years, Nat. Geosci., 9, 282-285, https://doi.org/10.1038/ngeo2665, 2016.

Welz, O., Savee, J. D., Osborn, D. L., Vasu, S. S., Percival, C. J., Shallcross, D. E., and Taatjes, C. A.: Direct Kinetic Measurements of Criegee Intermediate $\left(\mathrm{CH}_{2} \mathrm{OO}\right)$ Formed by Reaction of $\mathrm{CH}_{2} \mathrm{I}$ with $\mathrm{O}_{2}^{-}$, Science, 335, 204-207, https://doi.org/10.1126/science.1213229, 2012.

Wong, J. P. S., Yang, Y., Fang, T., Mulholland, J. A., Russell, A. G., Ebelt, S., Nenes, A., and Weber, R. J.: Fine Particle Iron in Soils and Road Dust Is Modulated by Coal-Fired Power Plant Sulfur, Environ. Sci. Technol., 54, 7088-7096, https://doi.org/10.1021/acs.est.0c00483, 2020.

Wozniak, A. S., Shelley, R. U., McElhenie, S. D., Landing, W. M., and Hatcher, P. G.: Aerosol water soluble organic matter characteristics over the North Atlantic Ocean: Implications for ironbinding ligands and iron solubility, Mar. Chem., 173, 162-172, https://doi.org/10.1016/j.marchem.2014.11.002, 2015.

Xu, L., Guo, H., Boyd, C. M., Klein, M., Bougiatioti, A., Cerully, K. M., Hite, J. R., Isaacman-VanWertz, G., Kreisberg, N. M., and Knote, C.: Effects of anthropogenic emissions on aerosol formation from isoprene and monoterpenes in the southeastern United States, P. Natl. Acad. Sci. USA, 112, 37-42, 2015.

Xue, J., Yuan, Z., Griffith, S. M., Yu, X., Lau, A. K. H., and Yu, J. Z.: Sulfate Formation Enhanced by a Cocktail of High $\mathrm{NOx}, \mathrm{SO}_{2}$, Particulate Matter, and Droplet $\mathrm{pH}$ during HazeFog Events in Megacities in China: An Observation-Based Modeling Investigation, Environ. Sci. Technol., 50, 7325-7334, https://doi.org/10.1021/acs.est.6b00768, 2016.

Yao, M., Zhao, Y., Hu, M. H., Huang, D. D., Wang, Y. C., Yu, J. Z., and Yan, N. Q.: Multiphase Reactions between Secondary Organic Aerosol and Sulfur Dioxide: Kinetics and Contributions to Sulfate Formation and Aerosol Aging, Environ. Sci. Technol. Lett., 6, 768-774, 10.1021/acs.estlett.9b00657, 2019.

Ye, C., Liu, P., Ma, Z., Xue, C., Zhang, C., Zhang, Y., Liu, J., Liu, C., Sun, X., and $\mathrm{Mu}$, Y.: High $\mathrm{H}_{2} \mathrm{O}_{2}$ Concentrations Observed during Haze Periods during the Winter in Beijing: Importance of $\mathrm{H}_{2} \mathrm{O}_{2}$ Oxidation in Sulfate Formation, Environ. Sci. Technol. Lett., 5, 757-763, https://doi.org/10.1021/acs.estlett.8b00579, 2018. 
Young, L.-H., Li, C.-H., Lin, M.-Y., Hwang, B.-F., Hsu, H.-T., Chen, Y.-C., Jung, C.-R., Chen, K.-C., Cheng, D.-H., and Wang, V.-S.: Field performance of a semi-continuous monitor for ambient $\mathrm{PM}_{2.5}$ water-soluble inorganic ions and gases at a suburban site, Atmos. Environ., 144, 376-388, 2016.

Yu, H., Li, W., Zhang, Y., Tunved, P., Dall'Osto, M., Shen, X., Sun, J., Zhang, X., Zhang, J., and Shi, Z.: Organic coating on sulfate and soot particles during late summer in the Svalbard Archipelago, Atmos. Chem. Phys., 19, 10433-10446, https://doi.org/10.5194/acp-19-10433-2019, 2019.

Yue, F., He, P., Chi, X., Wang, L., Yu, X., Zhang, P., and Xie, Z.: Characteristics and major influencing factors of sulfate production via heterogeneous transition-metal-catalyzed oxidation during haze evolution in China, Atmos. Pollut. Res., 11, 1351-1358, https://doi.org/10.1016/j.apr.2020.05.014, 2020.

Zelenov, V. V., Aparina, E. V., Kashtanov, S. A., and Shardakova, E. V.: Kinetics of $\mathrm{NO}_{3}$ uptake on a methane soot coating, Russ. J. Phys. Chem. B, 11, 180-188, https://doi.org/10.1134/s1990793117010146, 2017.

Zhang, B., Zhou, T., Liu, Y., Yan, C., Li, X., Yu, J., Wang, S., Liu, B., and Zheng, M.: Comparison of water-soluble inorganic ions and trace metals in $\mathrm{PM}_{2.5}$ between online and offline measurements in Beijing during winter, Atmos. Pollut. Res., 10, 17551765,https://doi.org/10.1016/j.apr.2019.07.007, 2019.

Zhang, N., Zhang, J., Zhang, Y., Bai, J., and Wei, X.: Solubility and Henry's law constant of sulfur dioxide in aqueous polyethylene glycol 300 solution at different temperatures and pressures, Fluid Phase Equilibria, 348, 9-16, https://doi.org/10.1016/j.fluid.2013.03.006, 2013.

Zhang, X., Zhuang, G., Chen, J., Wang, Y., Wang, X., An, Z., and Zhang, P.: Heterogeneous Reactions of Sulfur Dioxide on Typical Mineral Particles, J. Phys. Chem. B, 110, 12588-12596, https://doi.org/10.1021/jp0617773, 2006.
Zhao, D., Song, X., Zhu, T., Zhang, Z., Liu, Y., and Shang, J.: Multiphase oxidation of $\mathrm{SO}_{2}$ by $\mathrm{NO}_{2}$ on $\mathrm{CaCO}_{3}$ particles, Atmos. Chem. Phys., 18, 2481-2493, https://doi.org/10.5194/acp18-2481-2018, 2018.

Zhao, S., Tian, H., Luo, L., Liu, H., Wu, B., Liu, S., Bai, X., Liu, W., Liu, X., Wu, Y., Lin, S., Guo, Z., Lv, Y., and Xue, Y.: Temporal variation characteristics and source apportionment of metal elements in $\mathrm{PM}_{2.5}$ in urban Beijing during 2018-2019, Environ. Pollut., 268, 115856, https://doi.org/10.1016/j.envpol.2020.115856, 2021.

Zheng, B., Zhang, Q., Zhang, Y., He, K. B., Wang, K., Zheng, G. J., Duan, F. K., Ma, Y. L., and Kimoto, T.: Heterogeneous chemistry: a mechanism missing in current models to explain secondary inorganic aerosol formation during the January 2013 haze episode in North China, Atmos. Chem. Phys., 15, 2031-2049, https://doi.org/10.5194/acp-15-2031-2015, 2015.

Zheng, H., Song, S., Sarwar, G., Gen, M., Wang, S., Ding, D., Chang, X., Zhang, S., Xing, J., Sun, Y., Ji, D., Chan, C. K., Gao, J., and McElroy, M. B.: Contribution of Particulate Nitrate Photolysis to Heterogeneous Sulfate Formation for Winter Haze in China, Environ. Sci. Technol. Lett., 7, 632-638, https://doi.org/10.1021/acs.estlett.0c00368, 2020.

Zhu, Y., Tilgner, A., Hoffmann, E. H., Herrmann, H., Kawamura, K., Yang, L., Xue, L., and Wang, W.: Multiphase MCMCAPRAM modeling of the formation and processing of secondary aerosol constituents observed during the Mt. Tai summer campaign in 2014, Atmos. Chem. Phys., 20, 6725-6747, https://doi.org/10.5194/acp-20-6725-2020, 2020a.

Zhu, Y., Li, W., Lin, Q., Yuan, Q., Liu, L., Zhang, J., Zhang, Y., Shao, L., Niu, H., Yang, S., and Shi, Z.: Iron solubility in fine particles associated with secondary acidic aerosols in east China, Environ. Pollut., 264, 114769, https://doi.org/10.1016/j.envpol.2020.114769, 2020 b. 